\title{
Adjunct Culture of Non-Starter Lactic Acid Bacteria for the Production of Provola Dei Nebrodi PDO Cheese: In Vitro Screening and Pilot-Scale Cheese-Making
}

\author{
Cinzia Lucia Randazzo ${ }^{1}$, Luigi Liotta ${ }^{2}{ }^{\infty}$, Maria De Angelis ${ }^{3}\left(\mathbb{D}\right.$, Giuseppe Celano $^{3}{ }^{\oplus}$, Nunziatina Russo ${ }^{1}$, \\ Koenraad Van Hoorde ${ }^{4}$, Vincenzo Chiofalo ${ }^{5}$, Alessandra Pino ${ }^{1, *}(\mathbb{1})$ and Cinzia Caggia ${ }^{1}$ \\ 1 Department of Agricultural, Food and Environment, University of Catania, 95123 Catania, Italy; \\ cinzia.randazzo@unict.it (C.L.R.); nunziatinarusso83@gmail.com (N.R.); ccaggia@unict.it (C.C.) \\ 2 Department of Veterinary Sciences, University of Messina, 98168 Messina, Italy; luigi.liotta@unime.it \\ 3 Department of Soil, Plant and Food Science, University of Bari Aldo Moro, 70121 Bari, Italy; \\ maria.deangelis@uniba.it (M.D.A.); giuseppe.celano@uniba.it (G.C.) \\ 4 Department of Foodborne Pathogens, Sciensano, 1050 Brussels, Belgium; Koenraad.VanHoorde@sciensano.be \\ 5 Department of Chemical, Biological, Pharmaceutical and Environmental Sciences, University of Messina, \\ 98168 Messina, Italy; vincenzo.chiofalo@unime.it \\ * Correspondence: alessandra.pino@unict.it; Tel.: +39-32-0865-1071
}

check for updates

Citation: Randazzo, C.L.; Liotta, L.; Angelis, M.D.; Celano, G.; Russo, N.; Hoorde, K.V.; Chiofalo, V.; Pino, A.; Caggia, C. Adjunct Culture of

Non-Starter Lactic Acid Bacteria for the Production of Provola Dei Nebrodi PDO Cheese: In Vitro Screening and Pilot-Scale

Cheese-Making. Microorganisms 2021, 9, 179. https://doi.org/10.3390/ microorganisms 9010179

Received: 22 December 2020

Accepted: 13 January 2021

Published: 15 January 2021

Publisher's Note: MDPI stays neutral with regard to jurisdictional claims in published maps and institutional affiliations.

Copyright: (c) 2021 by the authors. Licensee MDPI, Basel, Switzerland. This article is an open access article distributed under the terms and conditions of the Creative Commons Attribution (CC BY) license (https:// creativecommons.org/licenses/by/ $4.0 /)$.

\begin{abstract}
The present study aimed at selecting non-starter lactic acid bacteria strains, with desirable technological and enzymatic activities, suitable as adjunct culture for the Provola dei Nebrodi cheese production. One hundred and twenty-one lactic acid bacteria, isolated from traditional Provola dei Nebrodi cheese samples, were genetically identified by Rep-PCR genomic fingerprinting, using the (GTG) 5 -primer, and by matrix-assisted laser desorption/ionisation time-of-flight mass spectrometry (MALDI-TOF MS). Twenty-seven strains, included in the qualified presumption of safety (QPS) list, were tested for technological and proteinase/peptidase activities. Results showed that technological features and flavour formation abilities were strain-dependent. Among the selected strains, Lacticaseibacillus paracasei PN 76 and Limosilactobacillus fermentum PN 101 were used as adjunct culture in pilot-scale cheese-making trials. Data revealed that adjunct cultures positively affected the flavour development of cheese, starting from 30 days of ripening, contributing to the formation of key flavour compounds. The volatile organic compound profiles of experimental cheeses was significantly different from those generated in the controls, suggesting that the selected adjunct strains were able to accelerate the flavour development, contributing to a unique profile of Provola dei Nebrodi cheese.
\end{abstract}

Keywords: traditional cheese; autochthonous strains; aminopeptidase activity; flavour formation; volatile organic compounds

\section{Introduction}

The Provola dei Nebrodi (PN) cheese is a historical Sicilian cheese, which has been recognized as a Protected Designation of Origin (PDO) cheese (GUUE L 309-23 September 2020). It is a full-fat raw milk semi-hard pasta filata cheese, produced in the Nebrodi Mountains area under traditional practices, using cow milk or a mix of cow, ewe and goat milk. Lamb or kid rennet paste is used for coagulation, and any starter culture is added during the cheese-making. The PN cheese is generally consumed as a fresh (less than 30 days old), semi-hard (30-120 days old), or hard (more than 120 days old) cheese-type and has a typical pear-like shape with a smooth, shiny, thin, yellow-gold surface and compact straw-coloured core. It is widely recognized that artisanal cheeses, produced under traditional practices using raw milk and without starter additions, boast unique and more intense sensorial characteristics than pasteurized milk cheeses. Their distinctive taste and flavour, greatly appreciated by consumers around the world, is mainly due, along with the environmental 
conditions and the cheese-making technology applied, to the lactic acid bacteria population (LAB) involved during the cheese production and ripening [1-3]. In particular, starter LAB (SLAB) are implicated in the lactose fermentation, producing high concentrations of lactic acid and enhancing the curd acidification, whereas non-starter LAB (NSLAB) are present during the cheese ripening, influencing the biochemistry of curd maturation and contributing to the development of the sensorial characteristics of the final product $[4,5]$. The NSLAB population plays a key role in cheese flavour compound development through three metabolic pathways: the metabolism of lactate and citrate, the release of free fatty acids and their subsequent metabolism, and the protein breakdown and amino acids catabolism [6-8]. It is well known that several NSLAB strains possess a comprehensive proteinase/peptidase system which include, besides the cell envelope-associated proteinase PrtP, several intracellular oligoendopeptidases (PepO, PapF, PepP), general aminopeptidases (PepN, PepC, PepG), glutamylaminopeptidase PepA, leucyl-aminopeptidase PepL, prolyl-dipeptidyl aminopeptidase PepX, tripeptidase (PepT), dipeptidase (PepQ, PepV) and several further proteinases/peptidases $[9,10]$. These proteinase/peptidase systems strongly influence the sensorial characteristics of both semi-hard and hard cheeses [11]. In particular, during cheese ripening, PepN positively influences both the saltiness and maturity indexes, and it is generally responsible for a reduction in sweetness and bitterness aromatic compounds. In addition, PepL is responsible for cheesy, chocolate, sweaty and malt aromas, whereas proline-aminopeptidase (PepI) is considered a good indicator of pronounced sourness [11]. In addition, NSLAB harbour a complex system of amino acid catabolizing enzymes [12]. Therefore, to ensure the enhancement of sensory properties of cheese, NSLAB strains, which can be used as adjunct cultures, should be carefully selected based on both technological parameters and enzymatic activities.

The present study aimed to select NSLAB strains to be used as adjunct cultures during the PN cheese production. To this end, NSLAB strains were isolated, genotypically characterized, and studied for their technological properties. Subsequently, selected strains were used in the PN cheese-making in order to validate, at pilot scale, their efficacy in the proteolytic metabolism during ripening.

\section{Materials and Methods}

\subsection{Cheese Samples and NSLAB Isolation}

The artisanal Provola dei Nebrodi PDO cheese (PN) samples, analysed in the present study, were produced under traditional practices in three different farms (I, II, and III) located in the surrounding area of the Nebrodi Mountains (Sicily, Italy). For each farm, semihard cheese samples (60 days old), obtained from three independent batches, were collected and transferred to the Laboratory of Microbiology (Department of Agricultural, Food, and Environment, University of Catania, Italy), under refrigerated conditions $\left(4 \pm 2{ }^{\circ} \mathrm{C}\right)$. Overall, 9 PN cheese samples (both core and surface sections) were subjected to NSLAB isolation according to Pino et al. [13], using de Man Rogosa and Sharpe (MRS) (Oxoid, Milan, Italy) agar medium, adjusted to $\mathrm{pH} 5.4$, incubated at $32{ }^{\circ} \mathrm{C}$ for $72 \mathrm{~h}$ (5 days) under microaerophilic conditions. Cycloheximide $100 \mathrm{mg} / \mathrm{mL}$ (Sigma, Milan, Italy), was added to inhibit yeast growth. From each MRS agar plate, about $20 \%$ of the colonies were randomly selected, checked for morphology, catalase activity, and Gram reaction, then purified, by streaking three times on MRS agar plates. Pure cultures were stored in liquid culture using $20 \%$ glycerol at $-80^{\circ} \mathrm{C}$.

\subsection{NSLAB Identification}

Total genomic DNA was extracted from NSLAB isolates by mechanical cell lysis following the protocol previously described [14]. DNA concentration was evaluated by measuring optical density using a Fluorometer Qubit (Invitrogen, Carlsbad, CA, USA). NSLAB identification was performed by Rep-PCR genomic fingerprinting, using a (GTG) - $_{5}$-primer, and matrix-assisted laser desorption/ionisation time-of-flight mass spectrometry (MALDI-TOF MS) (Bruker Daltonics, Germany) according to Nguyen et al., and Pino et al. [15,16]. 


\subsection{Safety Assessment}

\subsubsection{DNAse, Gelatinase, Haemolytic Activities and Mucin Degradation Ability}

NSLAB strains were evaluated for DNAse and gelatinase activities according to Lavilla-Lerma et al. [16]. Mucin degradation ability was tested following the method reported by Muñoz-Atienza et al. [17]. Haemolytic activity was evaluated on blood agar plates containing sheep blood (Biolife, Milan, Italy) according to Pino et al. [18]. The haemolytic positive strains Streptococcus pyogenes ATCC 19,615 and Streptococcus pneumoniae ATCC 6303 , cultured on Brain-Heart Infusion (BHI, Merck, Italy) at $37^{\circ} \mathrm{C}$ under $5 \%$ of $\mathrm{CO}_{2}$, were used as positive controls.

\subsubsection{Biogenic Amine Production}

The ability of the strains to produce biogenic amines by amino acid decarboxylation was tested according to Bover-Cid and Holzapfel [19] using tyrosine (freebase), histidine monohydrochloride, ornithine monohydrochloride or lysine monohydrochloride as precursor amino acids. Plates without amino acids were used as controls. All amino acids were purchased from Sigma.

\subsubsection{Antibiotic Susceptibility and Minimum Inhibitory Concentration Determination}

NSLAB isolates were evaluated for antibiotic susceptibility according to breakpoints proposed by the European Food Safety Authority (EFSA) [20]. The minimum inhibitory concentration (MIC) was determined by micro-dilution method according to Russo et al. [21] Strains showing MICs lower or higher than the EFSA's breakpoints were considered as sensitive or resistant, respectively [20].

\subsubsection{Genes for Virulence, Biogenic Amines, and Antibiotic Resistance}

A PCR-based approach was applied to investigate the presence of gene encoding virulence factors, biogenic amines production, and antibiotic resistance as reported by Pino et al. [16]. The amplicons were separated by electrophoresis on 0.8 to $2.0 \%(w / v)$ agarose gels in $0.5 \times$ TAE buffer, and gels were stained in $0.5 \times$ TAE buffer using the GelRed ${ }^{\circledR}$ Nucleic Acid Gel Stain (Biotium, Fremont, CA, USA).

\subsection{Technological Features}

\subsubsection{Salt Tolerance}

The lactobacilli strains, fulfilling the aforementioned safety properties, were tested for the ability to grow in saline solutions containing 2, 6, and $10 \%(w / v)$ of $\mathrm{NaCl}$ as reported by Ferrari et al. [22].

\subsubsection{Proteolytic and Lipolytic Activities, Exopolysaccharides and Diacetyl Production}

Proteolytic and lipolytic activities were evaluated according to Meng et al. [1] using Plate Count Agar supplemented with $1 \%(w / v)$ skim milk powder (Oxoid, Milan, Italy) and Tributyrin Agar (Merck, France) media, respectively. Exopolysaccharides (EPS) production was tested on both MRS and mMRS, in which glucose was replaced by $10 \%$ of sucrose, following the method described by Meng and co-workers [1]. The NSLAB strains' ability to produce diacetyl was evaluated according to Ribeiro et al. [23]. Diacetyl production was indicated by the formation of a red ring at the top of the tubes. Based on the presence and intensity of the red colour, the strains were scored as no $(-)$, moderate $(+)$, high $(++)$, or strong $(+++)$ diacetyl producers.

\subsubsection{Acidifying Activity}

To test acidifying activity, overnight cell cultures were grown in MRS broth at $37^{\circ} \mathrm{C}$, standardized to $9 \log \mathrm{cfu} / \mathrm{mL}$, and inoculated ( $2 \% v / v)$ into skim milk (Oxoid, Milan, Italy). The $\mathrm{pH}$ changes $(\Delta \mathrm{pH})$ were determined after $6-8 \mathrm{~h}$ of incubation at $37^{\circ} \mathrm{C}$ using a pH meter (H19017, Microprocessor, Hanna Instruments, Ronchi di Villafranca Padovana, Italy). 


\subsubsection{Peptidase Activities}

Aminopeptidase activities were evaluated on cell free extract (CFE) obtained from stationary phase cell cultures by lysozyme cell-lysis [24]. The p-nitroanilide (pNA) substrates Ala-pNA, Leu-pNA, Lys-pNA, Glu-pNA, and Pro-pNA were used according to González et al. [24]. One unit of aminopeptidase activity was considered as the enzyme amount able to determine an increase in absorbance of 0.001 units. Aminopeptidase activity was expressed as the number of activity units per milligram of protein per minute. The analyses were performed in triplicate and results are reported as mean and standard deviation.

\subsection{Experimental Pilot Scale Cheese-Making}

Two pilot-scale cheese-making trials, experimental (ECh) and control (CCh), were carried out in triplicate (three repetitions of each trial were conducted at different days) in a local dairy factory following the traditional cheese-making procedure and using $150 \mathrm{~L}$ of cow's milk. The experimental Provola dei Nebrodi cheeses (ECh) were obtained by adding the Lacticaseibacillus paracasei PN 76 and the Limosilactobacillus fermentum PN 101 strains, which were selected based on safety and technological properties as previously described. The aforementioned stains, used as an adjunct culture at a cell density of $10^{8} \mathrm{cfu} / \mathrm{mL}$, were inoculated in a 1:1 ratio before milk coagulation. The control Provola dei Nebrodi cheeses $(\mathrm{CCh})$ were obtained without any adjunct culture. Both experimental (ECh) and control (CCh) cheeses were collected at 0,30 and 60 days of ripening and were subjected to microbiological and physico-chemical analyses. For each trial, samples were collected and analysed in triplicate.

\subsection{Microbiological Analysis}

A mixture of both core and surface sections $(25 \mathrm{~g})$ of the ECh or CCh samples at 0,30 , and 60 days of ripening were subjected to total mesophilic bacteria, lactic acid bacteria, Enterobacteria, lactococci, yeasts, Listeria spp., Escherichia coli, faecal coliforms and staphylococci counts following the method and using the culture media reported by Pino et al. [14]. In addition, Kanamycin Aesculin Azide agar (KAA), incubated under anaerobic conditions at $37^{\circ} \mathrm{C}$ for $24-48 \mathrm{~h}$, was used for enterococci count. All media were purchased from Oxoid (Basingstoke, UK).

\subsection{Physico-Chemical Analysis}

A mix of both core and surface cheese sections (100 g) of CCh or ECh samples at 0,30 and 60 days of ripening were analysed for moisture, protein, fat, and salt content, using near-infrared spectroscopy in transmittance (FoodScanTM Dairy Analyser; FOSS, Hilleroed, Denmark). The ash content was determined following the Association of Official Analytical Chemists (AOAC) method (942.05 1942) [25]. In addition, the $\mathrm{pH}$ value of each sample was determined by pHmeter (H19017, Microprocessor, Hanna Instruments). Each analysis was conducted in triplicate and results are expressed in $\mathrm{g} / 100 \mathrm{~g}$ of edible part. The analyses were performed at the Laboratory of the Animal Production Unit, Department of Veterinary Sciences, University of Messina, Italy.

\subsection{Analysis of Volatile Organic Compounds (VOCs)}

Four grams of grated cheese, supplemented with $10 \mu \mathrm{L}$ of internal standard solution 4methyl-2-pentanol (33 ppm) were placed into $20 \mathrm{~mL}$ glass vials and sealed with polytetrafluoroethylene (PTFE)-coated silicone rubber septa (20 mm diameter) (Supelco, Bellefonte, PA, USA). In order to obtain the best extraction efficiency, the micro-extraction procedure was performed as described by Delgado et al. [26], with slight modifications. At the end of sample equilibration $\left(10 \mathrm{~min}\right.$ at $\left.50^{\circ} \mathrm{C}\right)$, a conditioned $50 / 30 \mu \mathrm{m} \mathrm{DVB} / \mathrm{CAR} / \mathrm{PDMS}$ fibre (Supelco, Bellefonte, PA, USA) was exposed to headspace at the same temperature for $60 \mathrm{~min}$ to obtain VOC adsorption. To keep the temperature constant during analysis, the vials were maintained on a heater plate (CTC Analytics, Zwingen, Switzerland) and the extraction was carried out by a CombiPAL system injector autosampler (CTC Analytics). 
The extracted compounds were desorbed in splitless mode for $3 \mathrm{~min}$ at $220^{\circ} \mathrm{C}$ and analysed by Clarus 680 (Perkien Elmer) gas-chromatography equipped with a capillary column Rtx-WAX column (30 m $\times 0.25 \mathrm{~mm}$ i.d., $0.25 \mu \mathrm{m}$ film thickness) (Restek, Bellfonte, PA, USA). The column temperature was set initially at $35^{\circ} \mathrm{C}$ for $8 \mathrm{~min}$, then increased to $60^{\circ} \mathrm{C}$ at $4{ }^{\circ} \mathrm{C} \mathrm{min}-1$, to $160{ }^{\circ} \mathrm{C}$ at $6{ }^{\circ} \mathrm{C} \mathrm{min}^{-1}$ and finally to $200{ }^{\circ} \mathrm{C}$ at $20^{\circ} \mathrm{C} \mathrm{min}^{-1}$ and held for $15 \mathrm{~min}$ [27]. Helium was used as the carrier gas at a flow rate of $1 \mathrm{~mL} \mathrm{~min}{ }^{-1}$. The analyses lasted for $50 \mathrm{~min}$. The single quadrupole mass spectrometer Clarus SQ 8C (Perkien Elmer) was coupled to the gas chromatography system. The source and transfer line temperatures were kept at 250 and $230{ }^{\circ} \mathrm{C}$, respectively. Electron ionisation masses were recorded at $70 \mathrm{eV}$, and the mass-to-charge ratio interval was 34 to $350 \mathrm{~m} / \mathrm{z}$. The GC-MS generated a chromatogram with peaks representing individual compounds. Each chromatogram was analysed for peak identification using the National Institute of Standard and Technology 2008 (NIST) library. A peak area threshold $>1,000,000$ and $85 \%$ or greater probability of match was used for VOC identification followed by manual visual inspection of the fragment patterns when required. The concentrations of VOCs, expressed as $\mathrm{mg} / \mathrm{kg}$, were calculated by using the internal standard.

\subsection{Statistical Analysis}

Acidifying activity, microbiological data, and VOC concentrations were subjected to ANOVA (one-way analysis of variance) followed by Tukey's post-hoc test. Statistical analysis was performed using XLSTAT PRO 5.7 (Addinsoft, New York, NY, USA) setting the reference level of significance to 0.05 in all assays. In addition, VOC data were subjected to permutation analysis using PermutMatrixEN software (Montpellier, France).

\section{Results}

\subsection{NSLAB Identification}

Overall, 160 isolates were obtained and 121 of them were found to be Gram-positive, catalase-negative, rod or coccal in shape, non-motile, and unable to form spores. As reported in Figure 1, REP-PCR analysis coupled to MALDI-TOF MS allowed the classification of them into six species. Overall, the isolates were ascribed to Limosilactobacillus fermentum (55\%), Enterococcus faecium (17\%), Pediococcus pentosaceus (16\%), Lacticaseibacillus paracasei (5\%), Enterococcus faecalis ( $5 \%$, and Lacticaseibacillus rhamnosus ( $2 \%$ ) species.

\subsection{Safety Properties}

Ninety-five (95) isolates, with the exception of those belonging to E. faecium and E. faecalis species, not included in the qualified presumption of safety (QPS) list, were screened for safety requirements. None of the tested strains showed the ability to produce DNAse and gelatinase, to degrade the mucin, and to exert haemolytic activity. Three strains (PN 6, PN 51, and PN 18), ascribed to P. pentosaceus were able to produce biogenic amines (BA) by the decarboxylation of tyrosine. NSLABs were susceptible to tested antibiotics with the exception of P. pentosaceus PN 21, PN 29, PN 73, PN 96, PN 118, and PN 126 strains which exhibited, for both gentamicin and erythromycin, MIC values higher than the EFSA breakpoints (Table 1). The PCR-based approach revealed the presence of genetic determinants conferring resistance to gentamicin and erythromycin only for the isolates exhibiting MIC values higher than the EFSA breakpoints. In addition, none of the tested isolates carried genes encoding for virulence factors and amino acid decarboxylation. 

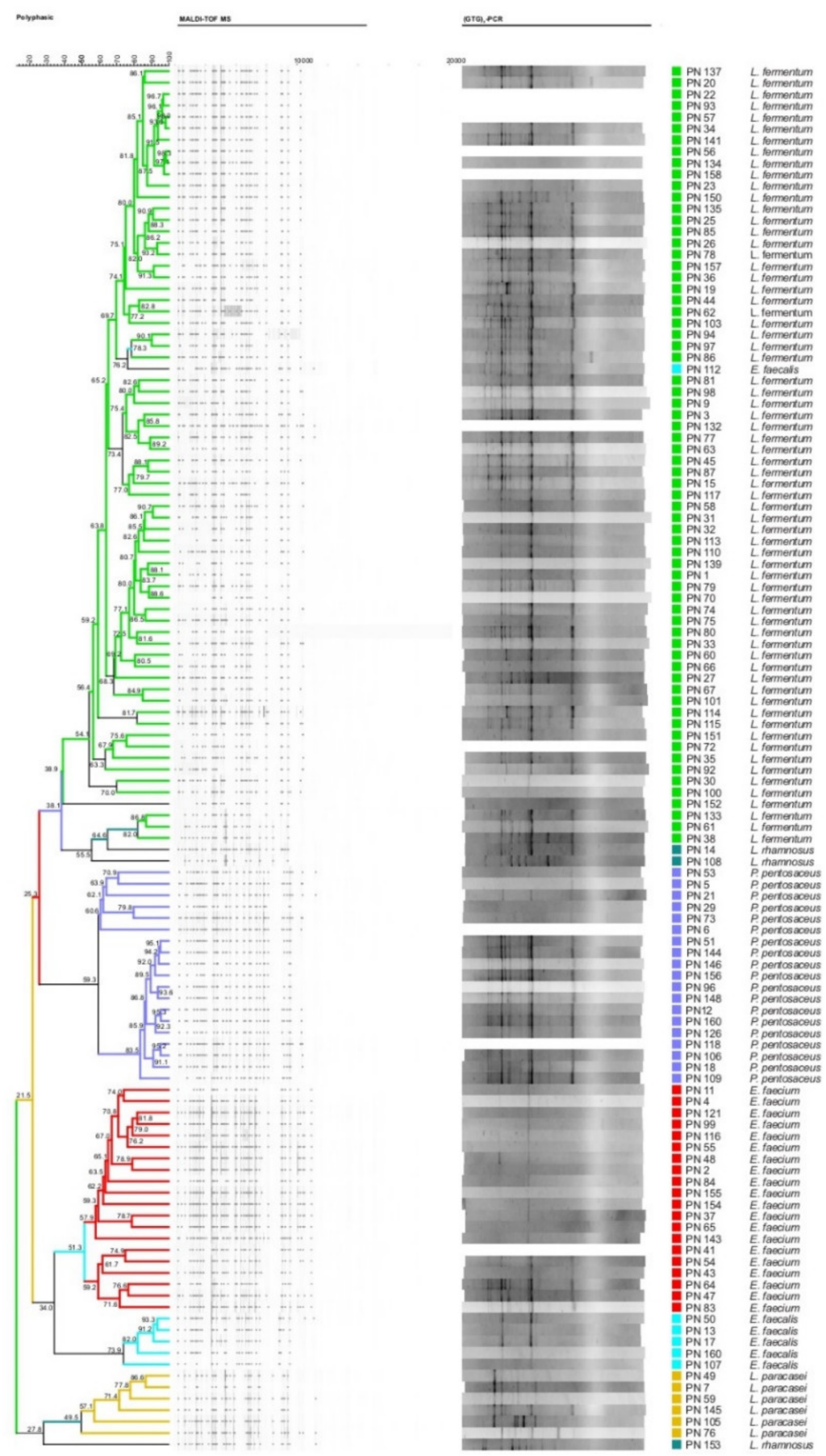

Figure 1. UPGMA dendrogram of the Rep-PCR and matrix-assisted laser desorption/ionisation time-of-flight mass spectrometry (MALDI-TOF MS) analyses of presumptive non-starter lactic acid bacteria (NSLAB) isolated from semi-hard Provola dei Nebrodi PDO (PN) cheese samples. Node values indicate the average percentage of similarity based on (GTG) $)_{5}$ PCR and MALDI-TOF MS profiles. The tree was made with BioNumerics version 5.1 . 
Table 1. Minimum inhibitory concentration (MIC) values showed by NSLAB strains obtained from 60-day ripened Provola dei Nebrodi PDO cheese samples.

\begin{tabular}{|c|c|c|c|c|c|c|c|c|c|c|c|c|c|c|c|c|c|}
\hline \multirow{2}{*}{ Antimicrobials } & \multirow{2}{*}{$\begin{array}{c}\text { Species } \\
\text { (No. of Tested Isolates) }\end{array}$} & \multicolumn{15}{|c|}{ Number of Strains which Showed the Indicated MIC Value $(\mathrm{mg} / \mathrm{L})^{\text {a }}$} & \multirow{2}{*}{$\begin{array}{l}\text { Breakpoints } \\
(\mathrm{mg} / \mathrm{L})^{\mathrm{b}}\end{array}$} \\
\hline & & 0.06 & 0.12 & 0.25 & 0.5 & 1 & 2 & 4 & 8 & 16 & 32 & 64 & 128 & 256 & 512 & 1024 & \\
\hline \multirow{4}{*}{ Ampicillin } & L. fermentum (67) & & 7 & 13 & 23 & 24 & & & & & & & & & & & 2 \\
\hline & P. pentosaceus (16) & & & & 13 & 3 & & & & & & & & & & & 4 \\
\hline & L. paracasei (6) & & & 1 & 5 & & & & & & & & & & & & 4 \\
\hline & L. rhamnosus (3) & & & 3 & & & & & & & & & & & & & 4 \\
\hline \multirow{4}{*}{ Gentamicin } & L. fermentum (67) & & & & 15 & 11 & 41 & & & & & & & & & & 16 \\
\hline & P. pentosaceus (16) & & & & & & 2 & 3 & 5 & & & 6 & & & & & 16 \\
\hline & L. paracasei (6) & & & & & & & 4 & & & & & & & & & 32 \\
\hline & L. rhamnosus (3) & & & & & & & & 3 & & & & & & & & 16 \\
\hline \multirow{4}{*}{ Kanamycin } & L. fermentum (67) & & & & & & 3 & 21 & & 43 & & & & & & & 32 \\
\hline & P. pentosaceus (16) & & & & & & & 6 & 10 & & & & & & & & 64 \\
\hline & L. paracasei (6) & & & & & & & & & 6 & & & & & & & 64 \\
\hline & L. rhamnosus (3) & & & & & & & 3 & & & & & & & & & 64 \\
\hline \multirow{4}{*}{ Streptomycin } & L. fermentum (67) & & & & & & & 13 & 21 & 18 & 15 & & & & & & 64 \\
\hline & P. pentosaceus (16) & & & & & & & & 16 & & & & & & & & 64 \\
\hline & L. paracasei (6) & & & & & & & & 1 & 5 & & & & & & & 64 \\
\hline & L. rhamnosus (3) & & & & & & 1 & 2 & & & & & & & & & 32 \\
\hline \multirow{3}{*}{ Erythromycin } & L. fermentum (67) & 15 & 21 & 28 & & & & & & & & & & & & & 1 \\
\hline & P. pentosaceus (16) & & 4 & 6 & & & & 2 & & 4 & & & & & & & 1 \\
\hline & L. rhamnosus (3) & & 2 & 1 & & & & & & & & & & & & & 1 \\
\hline \multirow{4}{*}{ Clindamycin } & L. fermentum (67) & & & 14 & 53 & & & & & & & & & & & & 1 \\
\hline & P. pentosaceus (16) & & 12 & & 4 & & & & & & & & & & & & 1 \\
\hline & L. paracasei (6) & & 4 & & & & & & & & & & & & & & 1 \\
\hline & L. rhamnosus (3) & & & 3 & & & & & & & & & & & & & 1 \\
\hline \multirow{4}{*}{ Tetracycline } & L. fermentum (67) & & & & 51 & 16 & & & & & & & & & & & 8 \\
\hline & P. pentosaceus (16) & & & & & & 16 & & & & & & & & & & 8 \\
\hline & L. paracasei (6) & & & 6 & & & & & & & & & & & & & 4 \\
\hline & L. rhamnosus (3) & & & & 3 & & & & & & & & & & & & 8 \\
\hline \multirow{4}{*}{ Chloramphenicol } & L. fermentum (67) & & & & & 51 & 16 & & & & & & & & & & 4 \\
\hline & P. pentosaceus (16) & & & 11 & 5 & & & & & & & & & & & & 4 \\
\hline & L. paracasei (6) & & & & 6 & & & & & & & & & & & & 4 \\
\hline & L. rhamnosus (3) & & & 2 & 1 & & & & & & & & & & & & 4 \\
\hline
\end{tabular}

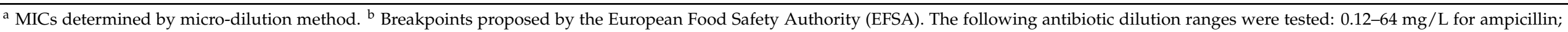

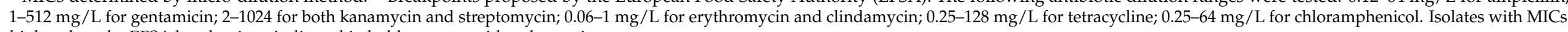
higher than the EFSA breakpoints, indicated in bold, were considered as resistant. 


\subsection{Technological Features}

\subsubsection{Salt Tolerance}

Sodium chloride tolerance exhibited by the tested NSLAB isolates is reported in Table 2. Overall, all stains were able to tolerate $2 \%$ of $\mathrm{NaCl}$. The ability to grow in the presence of $6 \%$ of $\mathrm{NaCl}$ was exhibited by 70 strains $(56 \mathrm{~L}$. fermentum, 5 P. pentosaceus, $6 \mathrm{~L}$. paracasei, and $3 \mathrm{~L}$. rhamnosus), whereas 27 strains ( 20 L. fermentum, 5 L. paracasei, and $2 \mathrm{~L}$. rhamnosus) tolerated a $\mathrm{NaCl}$ concentration of $10 \%$.

Table 2. Salt tolerance, proteolytic and lipolytic activities, exopolysaccharides (EPS) and diacetyl production exhibited by the NSLAB strains isolated from artisanal semi-hard Provola dei Nebrodi PDO (PN) cheese samples.

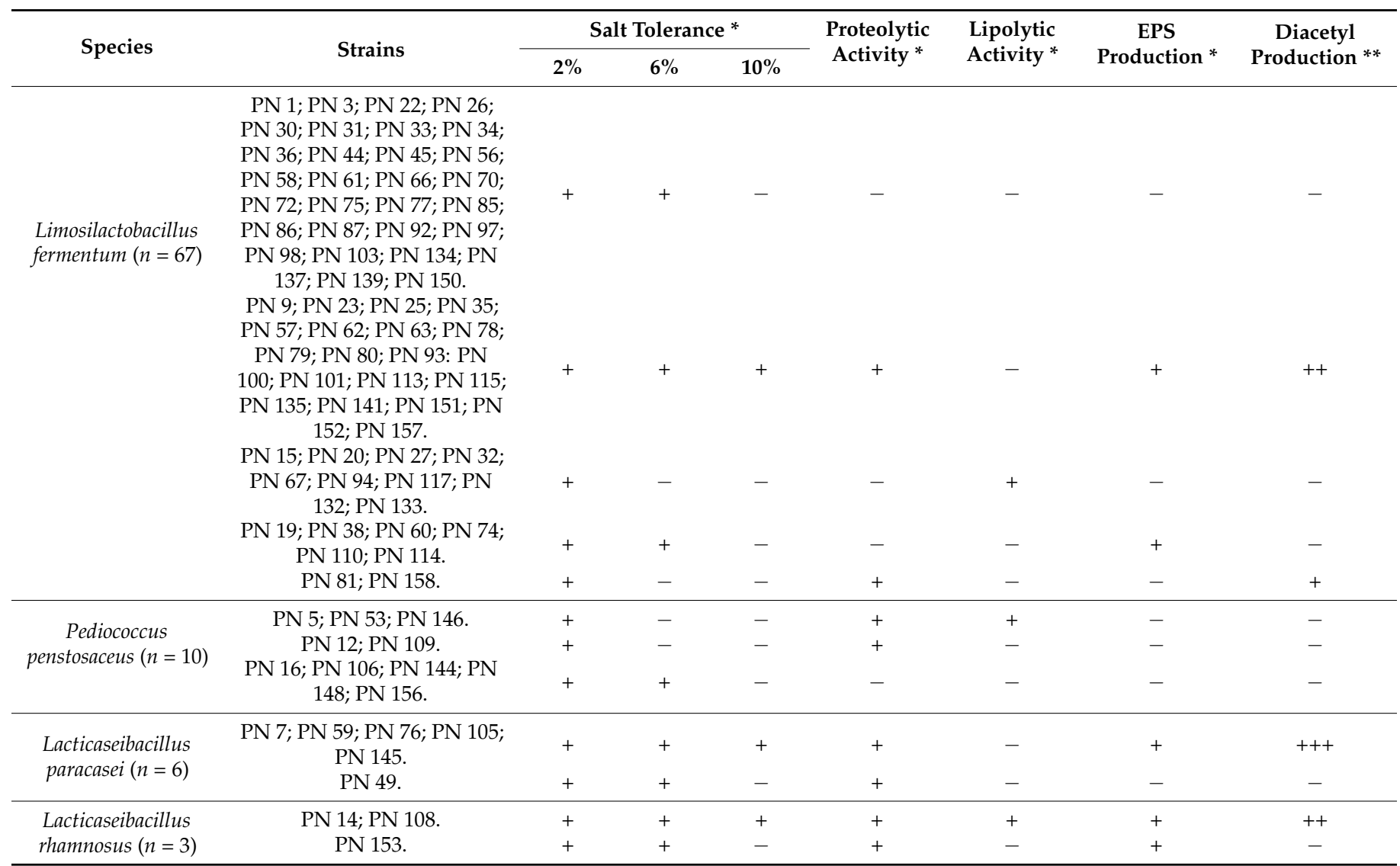

${ }^{*}(+)$ positive reaction; $(-)$ negative reaction. ${ }^{* *}$ The strains were scored as no $(-)$, moderate $(+)$, high $(++)$, or strong $(+++)$ diacetyl producer.

3.3.2. Proteolytic and Lipolytic Activities, Exopolysaccharides and Diacetyl Production Abilities

Table 2 shows the extracellular proteolytic and lipolytic activities, exopolysaccharides (EPS) and diacetyl production abilities exhibited by the 86 tested NSLABs. Regarding proteolytic activity, 36 isolates (42\%) showed transparent halo-forming colonies when grown on Plate Count Agar supplemented with 1\% $(w / v)$ skim milk powder. In particular, all the isolates ascribed to L. paracasei and L. rhamnosus species exhibited proteolytic activity, as well as $22 \mathrm{~L}$. fermentum and 5 P. pentosaceus strains (Table 2). Lipolytic activity, assayed on tributyrin agar (TBA), was shown by 14 strains (16\%). Among these, nine belonged to L. fermentum, three were ascribed to P. pentosaceus, and two were attributed to L. rhamnosus species. None of the L. paracasei isolates showed positive lipolytic capacity on the TBA medium. As reported in Table 2, 26 L. fermentum, 5 L. paracasei and 3 L. rhamnosus isolates were positive for EPS phenotypes, whereas none of the isolates ascribed to P. pentosaceus showed colonies with a slimy appearance. The ability to produce diacetyl from citrate was exhibited by 29 strains (34\%) (Table 2). Among these, 22 L. fermentum, 5 L. paracasei and 2 L. rhamnosus isolates exhibited high or strong diacetyl-producing capabilities. 


\subsubsection{Acidifying Activity}

The acidification activity of the isolates, selected based on the aforementioned technological properties, is reported in Figure 2. Overall, all the isolates showed slow acidification activity determining, after $6-8 \mathrm{~h}$ of incubation, a drop in $\mathrm{pH}$ values ranging from 0.24 to 0.75 .

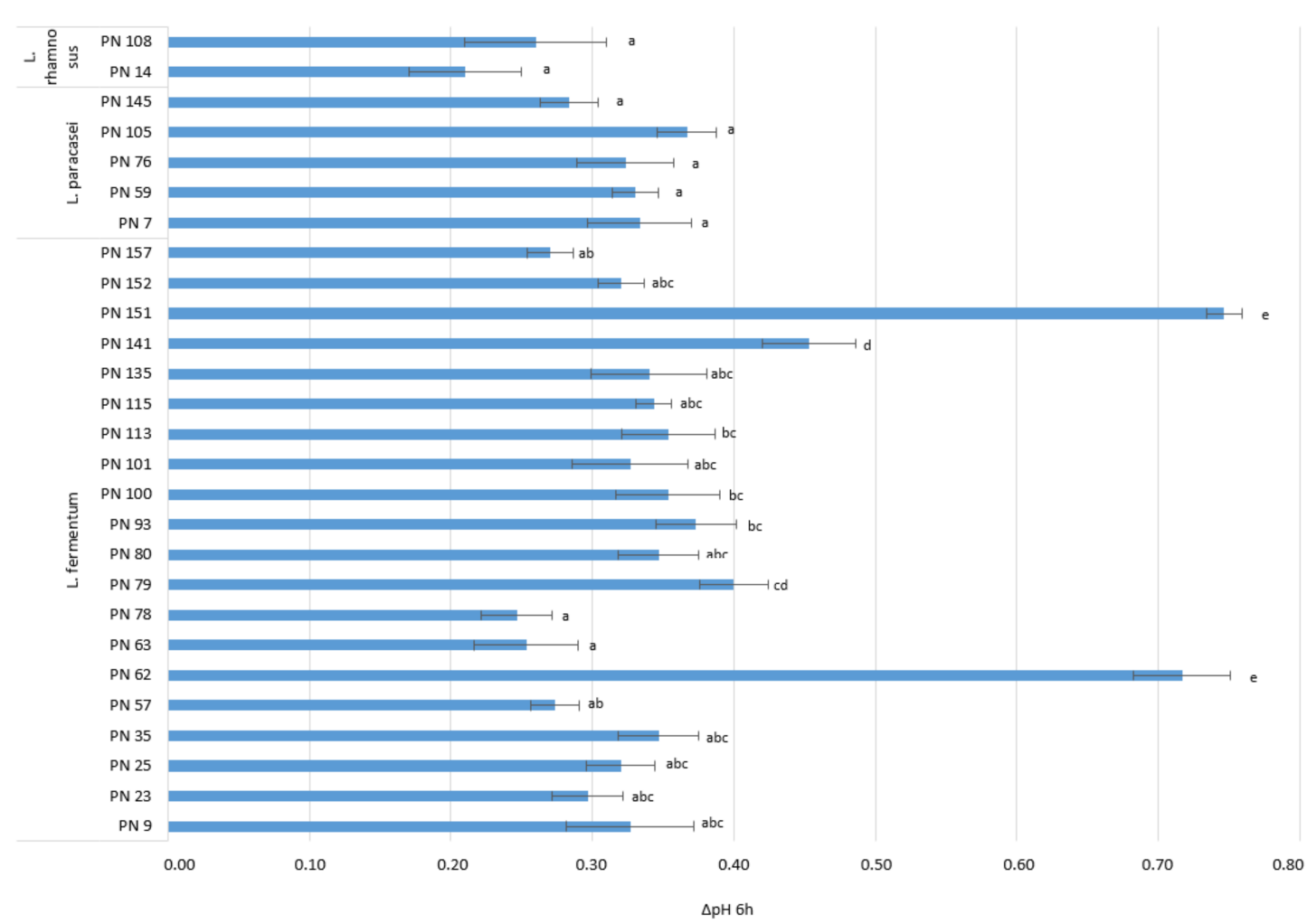

Figure 2. Acidification activity of the selected NSLAB strains isolated from artisanal semi-hard Provola dei Nebrodi PDO cheese samples. Results are reported as mean and standard deviation of three replicates. For each species, bars with different lowercase letters (a-e) are significantly different at $p<0.05$.

\subsubsection{Peptidase Activities}

Based on the aforementioned technological properties, 27 strains were tested for aminopeptidase activities, and results are reported in Table 3. Overall, the highest degree of aminopeptidase activity was recorded against the Lys-pNA substrate (range 120-0.42 activity units per milligram of protein per minute), whereas the lowest values were observed using the Ala-pNA substrate (range 2.29-0.16 activity units per milligram of protein per minute). All strains showed aminopeptidase activity towards the tested substrates with the exception of L. fermentum PN 135 and L. paracasei PN 105, which exhibited undetectable aminopeptidase activity towards both the Lys-pNA and the Glu-pNA substrates. L. fermentum PN 101 exhibited the highest aminopeptidase activity towards both Lys-pNA and Ala-pNA substrates, whereas the L. paracasei PN 76 stain appeared promising, showing the highest aminopeptidase activity toward both Leu-pNA and Pro-pNA substrates. 
Table 3. Peptidase activities of the NSLAB strains.

\begin{tabular}{|c|c|c|c|c|c|c|}
\hline Species & Strain & Pep N & Pep A & Pep L & Pep M & Pep I \\
\hline \multirow{20}{*}{ L. fermentum } & PN 9 & $76.77^{c} \pm 0.54$ & $0.16^{\mathrm{hm}} \pm 0.04$ & $7.73^{n} \pm 0.14$ & $19.23^{j} \pm 0.17$ & $35.63^{d} \pm 0.36$ \\
\hline & PN 23 & $42.08^{\mathrm{d}} \pm 0.17$ & $0.89^{\text {efg }} \pm 0.07$ & $0.25^{\mathrm{q}} \pm 0.05$ & $24.21^{\mathrm{fg}} \pm 0.13$ & $22.40^{\mathrm{i}} \pm 0.20$ \\
\hline & PN 25 & $0.5^{1} \pm 0.12$ & $2.29^{a} \pm 0.09$ & $26.44^{\mathrm{d}} \pm 0.33$ & $27.74^{\mathrm{d}} \pm 0.22$ & $24.77^{\mathrm{g}} \pm 0.18$ \\
\hline & PN 35 & $0.50^{1} \pm 0.06$ & $\begin{array}{c}0.70^{\text {eghim }} \pm \\
0.06\end{array}$ & $43.02^{a} \pm 0.14$ & $23.57^{\mathrm{fg}} \pm 0.32$ & $20.18^{\mathrm{k}} \pm 0.13$ \\
\hline & PN 57 & $10.63^{j} \pm 0.48$ & $0.75^{\text {eghm }} \pm 0.08$ & $25.69^{\mathrm{d}} \pm 0.31$ & $26.37^{e} \pm 0.26$ & $22.54^{\mathrm{i}} \pm 0.16$ \\
\hline & PN 62 & $17.41^{\mathrm{i}} \pm 0.47$ & $1.85^{\mathrm{b}} \pm 0.09$ & $14.11^{\mathrm{j}} \pm 0.13$ & $18.93^{j} \pm 0.16$ & $7.60 \mathrm{q} \pm 0.21$ \\
\hline & PN 63 & $19.45^{\mathrm{h}} \pm 0.46$ & $1.1^{\mathrm{cf}} \pm 0.10$ & $19.27^{\mathrm{f}} \pm 0.36$ & $5.58 \mathrm{pq} \pm 0.15$ & $13.28^{\mathrm{n}} \pm 0.14$ \\
\hline & PN 78 & $0.47^{1} \pm 0.12$ & $1.28^{\mathrm{c}} \pm 0.14$ & $17.57^{\mathrm{h}} \pm 0.35$ & $18.37^{\mathrm{j}} \pm 0.15$ & $28.23^{f} \pm 0.09$ \\
\hline & PN 79 & $18.54^{\mathrm{hi}} \pm 0.38$ & $\begin{array}{c}0.70 \text { eghim } \\
0.07\end{array}$ & $20.55^{\mathrm{eg}} \pm 0.37$ & $7.71^{\mathrm{n}} \pm 0.16$ & $32.83^{\mathrm{e}} \pm 0.13$ \\
\hline & PN 80 & $6.52^{\mathrm{k}} \pm 0.29$ & $1.85^{\mathrm{b}} \pm 0.10$ & $5.95^{\mathrm{a}} \pm 0.07$ & $30.63^{c} \pm 0.44$ & $16.87^{\mathrm{m}} \pm 0.26$ \\
\hline & PN 93 & $30.67^{\mathrm{e}} \pm 0.45$ & $1.43^{\mathrm{cd}} \pm 0.10$ & $10.68^{\operatorname{lm}} \pm 0.13$ & $4.57^{\mathrm{P}} \pm 0.36$ & $18.25^{1} \pm 0.22$ \\
\hline & PN 100 & $0.49^{1} \pm 0.07$ & $0.79^{\mathrm{eghm}} \pm 0.12$ & $17.37^{\mathrm{h}} \pm 0.35$ & $21.42^{\mathrm{h}} \pm 0.27$ & $10.29^{\mathrm{a}} \pm 0.14$ \\
\hline & PN 101 & $120.75^{\mathrm{a}} \pm 0.32$ & $0.37^{\mathrm{im}} \pm 0.05$ & $30.64^{b} \pm 0.37$ & $41.83^{\mathrm{a}} \pm 0.17$ & $39.63^{b} \pm 0.23$ \\
\hline & PN 113 & $0.48^{1} \pm 0.07$ & $0.71^{\text {eglm }} \pm 0.10$ & $29.26^{c} \pm 0.05$ & $7.12^{\mathrm{nq}} \pm 0.12$ & $23.74^{\mathrm{h}} \pm 0.18$ \\
\hline & PN 115 & $0.45^{1} \pm 0.06$ & $0.38^{\mathrm{hm}} \pm 0.06$ & $21.27^{\mathrm{e}} \pm 0.16$ & $16.72^{\mathrm{k}} \pm 0.16$ & $24.67^{\mathrm{gh}} \pm 0.27$ \\
\hline & PN 135 & ND & ND & $10.16^{\mathrm{m}} \pm 0.11$ & $24.51^{\mathrm{f}} \pm 0.23$ & $8.97 \mathrm{p} \pm 0.18$ \\
\hline & PN 141 & $0.46^{1} \pm 0.07$ & $0.67^{\mathrm{eghm}} \pm 0.09$ & $13.07^{\mathrm{k}} \pm 0.16$ & $5.29 \mathrm{pq} \pm 0.23$ & $37.63^{c} \pm 0.34$ \\
\hline & PN 151 & $0.44^{1} \pm 0.06$ & $0.66^{\mathrm{ghm}} \pm 0.10$ & $13.22^{\mathrm{j}} \pm 0.16$ & $16.65^{\mathrm{k}} \pm 0.14$ & $20.37^{\mathrm{jk}} \pm 0.27$ \\
\hline & PN 152 & $0.46^{1} \pm 0.16$ & $0.64^{\mathrm{ghm}} \pm 0.06$ & $19.57^{\mathrm{fg}} \pm 0.13$ & $15.07^{1} \pm 0.16$ & $9.21^{\mathrm{p}} \pm 0.16$ \\
\hline & PN 157 & $0.42^{1} \pm 0.04$ & $1.68^{b d} \pm 0.10$ & $0.85 \mathrm{pq} \pm 0.09$ & $14.74^{1} \pm 0.17$ & $19.69^{\mathrm{k}} \pm 0.26$ \\
\hline \multirow{5}{*}{ L. paracasei } & PN 7 & $0.45^{1} \pm 0.06$ & $1.19^{\mathrm{ce}} \pm 0.06$ & $7.58^{n} \pm 0.34$ & $6.14^{\mathrm{oq}} \pm 0.14$ & $21.30^{j} \pm 0.25$ \\
\hline & PN 59 & $26.54^{\mathrm{g}} \pm 0.45$ & $0.88^{\text {efg }} \pm 0.08$ & $11.57^{1} \pm 0.28$ & $9.42^{\mathrm{m}} \pm 0.20$ & $19.51^{\mathrm{k}} \pm 0.20$ \\
\hline & PN 76 & $96.65^{b} \pm 0.34$ & $\begin{array}{c}0.48^{\text {hilnop }} \pm \\
0.07\end{array}$ & $43.37^{\mathrm{a}} \pm 0.21$ & $33.54^{b} \pm 0.33$ & $47.61^{\mathrm{a}} \pm 0.22$ \\
\hline & PN 105 & ND & ND & $0.25 \mathrm{q} \pm 0.08$ & $19.63^{\mathrm{j}} \pm 0.31$ & $17.69^{\mathrm{lm}} \pm 0.17$ \\
\hline & PN 145 & $29.32^{f} \pm 0.23$ & $0.44^{\mathrm{mn}} \pm 0.05$ & $30.90^{\mathrm{b}} \pm 0.15$ & $6.61^{\text {no }} \pm 0.36$ & $13.66^{\mathrm{n}} \pm 0.18$ \\
\hline \multirow{2}{*}{ L. rhamnosus } & PN 14 & $0.44^{1} \pm 0.07$ & $0.83^{\text {efo }} \pm 0.09$ & $7.75^{n} \pm 0.17$ & $23.20^{g} \pm 0.18$ & $17.78^{\operatorname{lm}} \pm 0.19$ \\
\hline & PN 108 & $0.76^{1} \pm 0.07$ & $0.39 \mathrm{mp} \pm 0.07$ & $1.50 \mathrm{p} \pm 0.30$ & $6.58^{\text {noq }} \pm 0.21$ & $6.48^{\mathrm{r}} \pm 0.22$ \\
\hline
\end{tabular}

ND: not detected. Results are reported as mean and standard deviation of three replicates. Aminopeptidase activity was expressed as the number of activity units per milligram of protein per minute. One unit of aminopeptidase activity was considered as the enzyme amount able to determine an increase in absorbance of 0.001 units. Different letters $(a-p)$ in the same column indicate significant differences by one-way ANOVA test, followed by Tukey's post-hoc test $(p<0.05)$.

\subsection{Microbiological Analysis of Control and Experimental Cheeses}

Microbiological data of ECh and CCh cheese samples at 0,30 and 60 days of ripening, expressed as average values and standard deviations, are reported in Table 4. Regarding ECh samples, mesophilic aerobic bacteria, lactic acid bacteria, and lactococci showed a decreasing trend throughout the ripening time with a reduction of about $1 \log$ unit at 60 days of ripening. Enterobacteria, staphilococci, yeasts and enterococci exhibited a quite constant value up to 60 days of ripening. With regards to CCh samples, mesophilic aerobic bacteria, enterobacteria, and staphilococci showed a significant reduction at 60 days of ripening, whereas the number of lactobacilli, lactococci, yeasts, and enterococci revealed constant cell densities throughout the whole ripening time. Evaluating differences between ECh and CCh samples, statistical data revealed that the addition of adjunct cultures significantly influenced the level of lactobacilli and lactococci count, which showed, from the beginning of the ripening, higher values on ECh samples (Table 4). Moreover, the level of enterobacteria was significantly reduced by the addition of the adjunct cultures at both 0 and 30 days of ripening. Listeria spp., Escherichia coli and faecal coliforms were never detected in the analysed samples (Table 4). 
Table 4. Microbial counts expressed as $\log _{10} \mathrm{cfu} / \mathrm{mL}$ and standard deviation (SD) of the main microbial groups detected in experimental (ECh) and control (CCh) cheeses at 0,30 and 60 days of ripening.

\begin{tabular}{ccccccc}
\hline \multirow{2}{*}{ Media } & \multicolumn{3}{c}{ ECh } & \multicolumn{3}{c}{ Ch } \\
\cline { 2 - 7 } & $\mathbf{0}$ & $\mathbf{3 0}$ & $\mathbf{6 0}$ & $\mathbf{0}$ & $\mathbf{3 0}$ & $\mathbf{6 0}$ \\
\hline PCA & $9.50^{\mathrm{d}} \pm 0.14$ & $8.93^{\mathrm{c}} \pm 0.07$ & $8.63^{\mathrm{bc}} \pm 0.08$ & $8.34^{\mathrm{b}} \pm 0.05$ & $8.84^{\mathrm{c}} \pm 0.07$ & $7.96^{\mathrm{a}} \pm 0.10$ \\
MRS & $9.29^{\mathrm{c}} \pm 0.07$ & $8.77^{\mathrm{b}} \pm 0.14$ & $8.74^{\mathrm{b}} \pm 0.06$ & $7.80^{\mathrm{a}} \pm 0.05$ & $7.88^{\mathrm{a}} \pm 0.10$ & $7.63^{\mathrm{a}} \pm 0.09$ \\
VRBA $^{*}$ & $1.19^{\mathrm{ab}} \pm 0.11$ & $1.36^{\mathrm{b}} \pm 0.09$ & $1.04^{\mathrm{a}} \pm 0.07$ & $1.73^{\mathrm{c}} \pm 0.07$ & $1.85^{\mathrm{c}} \pm 0.09$ & $1.09^{\mathrm{ab}} \pm 0.08$ \\
M17 & $9.23^{\mathrm{d}} \pm 0.06$ & $8.87^{\mathrm{c}} \pm 0.09$ & $8.13^{\mathrm{b}} \pm 0.06$ & $7.72^{\mathrm{a}} \pm 0.07$ & $7.84^{\mathrm{a}} \pm 0.07$ & $7.60^{\mathrm{a}} \pm 0.10$ \\
SDA & $2.86^{\mathrm{b}} \pm 0.07$ & $2.30^{\mathrm{a}} \pm 0.13$ & $2.27^{\mathrm{a}} \pm 0.07$ & $2.32^{\mathrm{a}} \pm 0.08$ & $2.26^{\mathrm{a}} \pm 0.07$ & $2.18^{\mathrm{a}} \pm 0.07$ \\
MSA & $1.64^{\mathrm{b}} \pm 0.10$ & $1.13^{\mathrm{a}} \pm 0.09$ & $1.04^{\mathrm{a}} \pm 0.07$ & $2.29^{\mathrm{c}} \pm 0.12$ & $1.24^{\mathrm{a}} \pm 0.06$ & $1.03^{\mathrm{a}} \pm 0.09$ \\
KAA & $5.23^{\mathrm{a}} \pm 0.09$ & $5.38^{\mathrm{a}} \pm 0.11$ & $5.31^{\mathrm{a}} \pm 0.06$ & $5.26^{\mathrm{a}} \pm 0.10$ & $5.34^{\mathrm{a}} \pm 0.09$ & $5.28^{\mathrm{a}} \pm 0.06$ \\
\hline
\end{tabular}

* incubated at $37^{\circ} \mathrm{C}$. Plate Count Agar (PCA), de Man Rogosa and Sharpe (MRS), Violet Red Bile Agar (VRBA), M17 Agar (M17), Sabouraud dextrose agar (SDA), Mannitol salt agar (MSA), Kanamycin Aesculin Azide agar (KAA). Different lowercase letters (a-d) in the same row, indicate a significant difference among experimental (ECh) or control (CCh) cheese samples at $p<0.05$ (ANOVA with Tukey's post-hoc test).

\subsection{Physico-Chemical Analysis}

The physico-chemical composition of experimental (ECh) and control (CCh) cheese samples at 0,30 and 60 days of ripening are reported in Table 5. Overall, at the same time of ripening, no significant differences were recorded among the analysed samples.

Table 5. Physico-chemical characteristics of experimental (ECh) and control (CCh) cheeses at 0, 30 and 60 days of ripening.

\begin{tabular}{ccccccc}
\hline \multirow{2}{*}{ Parameters } & \multicolumn{4}{c}{ ECh } & \multicolumn{2}{c}{ CCh } \\
\cline { 2 - 7 } & $\mathbf{0}$ & $\mathbf{3 0}$ & $\mathbf{6 0}$ & $\mathbf{0}$ & $\mathbf{3 0}$ & $\mathbf{6 0}$ \\
\hline $\mathrm{pH}$ & $5.65^{\mathrm{b}} \pm 0.02$ & $5.52^{\mathrm{b}} \pm 0.01$ & $5.43^{\mathrm{a}} \pm 0.08$ & $5.81^{\mathrm{b}} \pm 0.03$ & $5.66^{\mathrm{a}} \pm 0.01$ & $5.48^{\mathrm{a}} \pm 0.10$ \\
Moisture & $44.81^{\mathrm{c}} \pm 0.15$ & $40.76^{\mathrm{b}} \pm 0.03$ & $34.58^{\mathrm{a}} \pm 0.05$ & $44.25^{\mathrm{c}} \pm 0.12$ & $40.88^{\mathrm{b}} \pm 1.09$ & $34.86^{\mathrm{a}} \pm 1.29$ \\
Protein & $26.98^{\mathrm{a}} \pm 0.22$ & $28.66^{\mathrm{a}} \pm 0.08$ & $30.08^{\mathrm{b}} \pm 0.06$ & $27.25^{\mathrm{a}} \pm 0.14$ & $28.34^{\mathrm{a}} \pm 0.44$ & $29.80^{\mathrm{a}} \pm 0.59$ \\
Fat & $23.56^{\mathrm{a}} \pm 0.11$ & $25.78^{\mathrm{a}} \pm 0.03$ & $30.03^{\mathrm{b}} \pm 0.04$ & $23.62^{\mathrm{a}} \pm 0.19$ & $25.90^{\mathrm{a}} \pm 0.34$ & $29.90^{\mathrm{b}} \pm 0.70$ \\
Salt & $1.54^{\mathrm{a}} \pm 0.20$ & $2.01^{\mathrm{b}} \pm 0.02$ & $1.83^{\mathrm{b}} \pm 0.01$ & $1.40^{\mathrm{a}} \pm 0.04$ & $2.04^{\mathrm{b}} \pm 0.03$ & $1.91^{\mathrm{b}} \pm 0.02$ \\
Ash & $2.89^{\mathrm{a}} \pm 0.28$ & $2.88^{\mathrm{a}} \pm 0.03$ & $3.33^{\mathrm{b}} \pm 0.01$ & $2.78^{\mathrm{a}} \pm 0.03$ & $2.70^{\mathrm{a}} \pm 0.07$ & $3.47^{\mathrm{b}} \pm 0.08$ \\
\hline
\end{tabular}

Different lowercase letters $(\mathrm{a}-\mathrm{c})$ in the same row, indicate a significant difference among experimental (ECh) or control (CCh) cheese samples at $p<0.05$ (ANOVA with Tukey's post-hoc test).

\subsection{Volatile Organic Compounds (VOCs) Detection}

The VOCs detected in ECh and CCh cheese samples at 0, 30, and 60 days of ripening are reported in Table 6 . In addition, similarities in the observed metabolomics profiles between ECh and CCh samples, estimated using the PermutMatrixEN software, are displayed in Figure 3. Overall, the analysis allowed the identification of 51 compounds as alcohols, aldehydes, esters, ketones, organic acids, and terpenes. Organic acids represented the main VOCs detected, whereas aldehydes were the less abundant. Total VOCs exhibited a growing trend during the ripening time in all the analysed samples, reaching the highest value in ECh samples at 60 days of ripening $(219.34 \mathrm{mg} / \mathrm{kg})$. Focusing on each chemical class, statistically significant differences were recorded among samples. In particular, among organic acids, hexanoic acid, butanoic acid, acetic acid, propanoic acid, and pentanoic acid were detected at higher concentrations in ECh samples at 60 days of ripening. Similarly, among alcohols, phenylethyl alcohol, benzyl alcohol, and 2,3-butanediol were mainly detected in ECh samples at 60 days of ripening, whereas 3-methyl-1-butanol, 2-butanol, and 1-butanol reached the highest concentration in ECh samples, at both 30 and 60 days of ripening. Ethyl hexanoate, ethyl octanoate, ethyl butanoate, ethyl decanoate, and ethyl acetate were significantly different among ECh and CCh samples at both 30 and 60 days of ripening, whereas ethyl propanoate, 2-butanol acetate, phenylethyl acetate, and 3-methylbutyl butanoate were detected only in ECh samples at 30 and 60 days of ripening. Among ketones, 2-butanone, diacetyl, acetoin, and 2-undecanone were significantly different among ECh and $\mathrm{CCh}$ samples at 30 days of ripening. In addition, the aforementioned ketones were 
not detected in ECh samples at 60 days of ripening. Among terpenes, beta-pinene was revealed only in CCh samples at 0 and 30 days of ripening.

Table 6. Volatile organic compounds (VOCs) (mg/ $\mathrm{kg}$ ) identified in experimental (ECh) and control (CCh) cheeses at 0 , 30 and 60 days of ripening. Data are the means and standard deviations of three independent experiments analysed in duplicate.

\begin{tabular}{|c|c|c|c|c|c|c|}
\hline \multirow{3}{*}{ VOCs } & \multicolumn{6}{|c|}{ Cheese Samples } \\
\hline & \multicolumn{3}{|c|}{ ECh } & \multicolumn{3}{|c|}{$\mathrm{CCh}$} \\
\hline & 0 & 30 & 60 & 0 & 30 & 60 \\
\hline \multicolumn{7}{|l|}{ Organic acids } \\
\hline Hexanoic acid & $5.67^{\mathrm{d}} \pm 0.007$ & $17.23^{c} \pm 2.616$ & $49.67^{\mathrm{a}} \pm 3.714$ & $9.61^{\mathrm{d}} \pm 0.662$ & $15.37^{\mathrm{c}} \pm 0.556$ & $36.65^{b} \pm 1.647$ \\
\hline Butanoic acid & $2.14^{\mathrm{d}} \pm 0.007$ & $11.70^{c} \pm 1.680$ & $38.21^{\mathrm{a}} \pm 2.454$ & $4.53^{\mathrm{d}} \pm 0.363$ & $9.07^{\mathrm{c}} \pm 0.597$ & $20.17^{b} \pm 0.950$ \\
\hline Octanoic acid & $2.04^{c} \pm 0.144$ & $6.02^{b} \pm 0.960$ & $18.62^{\mathrm{a}} \pm 3.102$ & $3.68^{b c} \pm 0.271$ & $5.44^{b c} \pm 0.135$ & $20.62^{a} \pm 0.596$ \\
\hline Acetic acid & $0.59^{\mathrm{d}} \pm 0.095$ & $5.00^{b c} \pm 0.904$ & $18.49^{\mathrm{a}} \pm 2.221$ & $1.59^{\mathrm{d}} \pm 0.165$ & $2.75^{\mathrm{cd}} \pm 0.117$ & $7.27^{b} \pm 0.800$ \\
\hline n-Decanoic acid & $0.89^{b} \pm 0.063$ & $2.57^{b} \pm 0.421$ & $8.10^{\mathrm{a}} \pm 1.809$ & $1.21^{\mathrm{b}} \pm 0.075$ & $1.91^{\mathrm{b}} \pm 0.169$ & $7.63^{a} \pm 0.341$ \\
\hline Propanoic acid & ND & $0.74^{b} \pm 0.387$ & $1.91^{\mathrm{a}} \pm 0.868$ & ND & $0.03^{b} \pm 0.005$ & $0.39^{b} \pm 0.010$ \\
\hline Nonanoic acid & $0.10^{c} \pm 0.052$ & $0.38^{b c} \pm 0.133$ & $0.79^{a} \pm 0.008$ & $0.25^{\mathrm{c}} \pm 0.015$ & $0.71^{\mathrm{ab}} \pm 0.287$ & $0.83^{\mathrm{a}} \pm 0.032$ \\
\hline Heptanoic acid & $0.07^{\mathrm{c}} \pm 0.002$ & $0.23^{b} \pm 0.043$ & $0.72^{\mathrm{a}} \pm 0.109$ & $0.16^{\mathrm{c}} \pm 0.02 \mathrm{~b}$ & $0.24^{b} \pm 0.006$ & $0.81^{\mathrm{a}} \pm 0.053$ \\
\hline 3-Methylbutanoic acid & $0.01^{\mathrm{a}} \pm 0.007$ & $0.57^{\mathrm{a}} \pm 0.516$ & $1.44^{\mathrm{a}} \pm 1.342$ & ND & $0.04^{\mathrm{a}} \pm 0.006$ & ND \\
\hline Pentanoic acid & $0.06^{\mathrm{d}} \pm 0.002$ & $0.26^{c} \pm 0.041$ & $0.76^{\mathrm{a}} \pm 0.049$ & $0.09^{\mathrm{d}} \pm 0.003$ & $0.21^{\mathrm{c}} \pm 0.020$ & $0.47^{\mathrm{b}} \pm 0.016$ \\
\hline Dodecanoic acid & $0.07^{b} \pm 0.007$ & $0.19^{b} \pm 0.027$ & $0.65^{\mathrm{a}} \pm 0.162$ & $0.10^{\mathrm{b}} \pm 0.006$ & $0.12^{b} \pm 0.004$ & $0.69^{a} \pm 0.058$ \\
\hline 9-Decenoic acid & $0.07^{b} \pm 0.011$ & $0.21^{\mathrm{b}} \pm 0.035$ & $0.69^{a} \pm 0.179$ & $0.09^{b} \pm 0.012$ & $0.13^{b} \pm 0.009$ & $0.62^{\mathrm{a}} \pm 0.012$ \\
\hline \multicolumn{7}{|l|}{ Alcohols } \\
\hline Ethanol & $0.30^{b} \pm 0.068$ & $1.30^{b} \pm 0.130$ & $4.58^{a} \pm 0.812$ & $0.71^{b} \pm 0.054$ & $0.37^{b} \pm 0.016$ & $7.80^{a} \pm 0.970$ \\
\hline 3-Methyl-1-butanol & $0.15^{\mathrm{d}} \pm 0.026$ & $1.12^{b} \pm 0.315$ & $2.76^{\mathrm{a}} \pm 0.800$ & $0.24^{\mathrm{cd}} \pm 0.004$ & $0.23^{\mathrm{cd}} \pm 0.026$ & $0.15^{\mathrm{d}} \pm 0.046$ \\
\hline Phenylethyl alcohol & $0.20^{b} \pm 0.018$ & $1.21^{\mathrm{ab}} \pm 0.947$ & $2.36^{\mathrm{a}} \pm 1.470$ & $0.19^{b} \pm 0.006$ & $0.24^{b} \pm 0.001$ & $0.35^{b} \pm 0.007$ \\
\hline Benzyl alcohol & $0.12^{b} \pm 0.018$ & $0.32^{b} \pm 0.044$ & $1.14^{\mathrm{a}} \pm 0.423$ & $0.17^{b} \pm 0.048$ & $0.37^{b} \pm 0.111$ & $0.44^{\mathrm{b}} \pm 0.090$ \\
\hline 2-Butanol & ND & $0.07^{\mathrm{c}} \pm 0.003$ & $0.15^{\mathrm{b}} \pm 0.009$ & ND & $0.18^{a} \pm 0.013$ & $0.06^{\mathrm{c}} \pm 0.002$ \\
\hline 1-Butanol & ND & $0.07^{c} \pm 0.006$ & $0.17^{\mathrm{a}} \pm 0.010$ & ND & $0.02^{\mathrm{d}} \pm 0.002$ & $0.11^{b} \pm 0.007$ \\
\hline 2,3-Butanediol & ND & $0.04^{c} \pm 0.008$ & $0.19^{a} \pm 0.030$ & ND & ND & $0.07^{\mathrm{b}} \pm 0.007$ \\
\hline 1-Hexanol & $0.01^{\mathrm{e}} \pm 0.006$ & $0.03^{c} \pm 0.000$ & $0.08^{b} \pm 0.009$ & $0.02^{\text {de }} \pm 0.001$ & $0.02^{\mathrm{cd}} \pm 0.002$ & $0.12^{\mathrm{a}} \pm 0.002$ \\
\hline Phenol & $0.01^{\mathrm{a}} \pm 0.007$ & $0.01^{\mathrm{a}} \pm 0.013$ & ND & $0.01^{\mathrm{a}} \pm 0.006$ & $0.01^{\mathrm{a}} \pm 0.010$ & ND \\
\hline \multicolumn{7}{|l|}{ Esters } \\
\hline Ethyl hexanoate & $0.11^{\mathrm{d}} \pm 0.012$ & $10.12^{\mathrm{c}} \pm 1.033$ & $34.23^{a} \pm 4.790$ & $0.47^{\mathrm{d}} \pm 0.039$ & $1.47^{\mathrm{d}} \pm 0.139$ & $19.8^{\mathrm{b}} \pm 0.682$ \\
\hline Ethyl octanoate & $0.08^{\mathrm{d}} \pm 0.002$ & $3.98^{c} \pm 0.023$ & $14.14^{\mathrm{a}} \pm 0.523$ & $0.14^{\mathrm{d}} \pm 0.014$ & $0.52^{\mathrm{d}} \pm 0.002$ & $9.31^{\mathrm{b}} \pm 0.808$ \\
\hline Ethyl butanoate & $0.03^{\mathrm{d}} \pm 0.002$ & $0.65^{c} \pm 0.049$ & $5.16^{\mathrm{a}} \pm 0.044$ & $0.06^{\mathrm{d}} \pm 0.002$ & $0.14^{\mathrm{d}} \pm 0.018$ & $2.12^{b} \pm 0.286$ \\
\hline Ethyl decanoate & $0.04^{\mathrm{d}} \pm 0.003$ & $0.57^{\mathrm{c}} \pm 0.030$ & $2.74^{\mathrm{a}} \pm 0.081$ & $0.04^{\mathrm{d}} \pm 0.001$ & $0.07^{\mathrm{d}} \pm 0.003$ & $1.65^{b} \pm 0.171$ \\
\hline Propyl hexanoate & ND & $0.68^{b} \pm 0.006$ & $2.08^{a} \pm 0.180$ & ND & $0.02^{\mathrm{c}} \pm 0.005$ & $0.69^{b} \pm 0.042$ \\
\hline Ethyl acetate & $0.07^{\mathrm{c}} \pm 0.021$ & $0.50^{\mathrm{b}} \pm 0.008$ & $1.14^{\mathrm{a}} \pm 0.197$ & $0.05^{c} \pm 0.005$ & $0.05^{c} \pm 0.007$ & $0.16^{\mathrm{c}} \pm 0.010$ \\
\hline Ethyl n-dodecanoate & ND & $0.26^{\mathrm{c}} \pm 0.015$ & $0.90^{\mathrm{a}} \pm 0.100$ & ND & ND & $0.57^{\mathrm{b}} \pm 0.044$ \\
\hline Ethyl propanoate & ND & $0.33^{b} \pm 0.016$ & $1.06^{\mathrm{a}} \pm 0.135$ & ND & ND & ND \\
\hline 3-Methylbutyl acetate & ND & $0.40^{\mathrm{b}} \pm 0.177$ & $0.76^{\mathrm{a}} \pm 0.131$ & ND & ND & $0.22^{b} \pm 0.038$ \\
\hline Ethyl hexanoate & ND & $0.15^{\mathrm{c}} \pm 0.003$ & $0.58^{a} \pm 0.023$ & ND & ND & $0.39^{b} \pm 0.045$ \\
\hline 2-Butanol acetate & ND & $0.26^{\mathrm{b}} \pm 0.026$ & $0.56^{\mathrm{a}} \pm 0.010$ & ND & ND & ND \\
\hline Propyl octanoate & ND & $0.12^{c} \pm 0.006$ & $0.46^{\mathrm{a}} \pm 0.011$ & ND & ND & $0.21^{\mathrm{b}} \pm 0.004$ \\
\hline Methyl isobutyrate & ND & $0.03^{c} \pm 0.000$ & $0.37^{\mathrm{a}} \pm 0.029$ & ND & ND & $0.23^{b} \pm 0.022$ \\
\hline Ethyl 9-decenoate & ND & $0.07^{c} \pm 0.008$ & $0.34^{\mathrm{a}} \pm 0.016$ & ND & ND & $0.18^{\mathrm{b}} \pm 0.018$ \\
\hline Phenylethyl acetate & $0.01^{\mathrm{a}} \pm 0.007$ & $0.15^{\mathrm{a}} \pm 0.102$ & $0.14^{\mathrm{a}} \pm 0.105$ & ND & ND & ND \\
\hline Ethyl nonanoate & ND & $0.0^{\mathrm{c}} \pm 0.005$ & $0.14^{\mathrm{a}} \pm 0.001$ & ND & ND & $0.07^{\mathrm{b}} \pm 0.011$ \\
\hline Ethyl pentanoate & ND & $0.01^{\mathrm{b}} \pm 0.012$ & $0.10^{\mathrm{a}} \pm 0.007$ & ND & ND & $0.08^{c} \pm 0.007$ \\
\hline Propyl decanoate & ND & $0.02^{c} \pm 0.001$ & $0.08^{a} \pm 0.013$ & ND & ND & $0.05^{\mathrm{b}} \pm 0.000$ \\
\hline $\begin{array}{l}\text { 3-Methylbutyl } \\
\text { butanoate }\end{array}$ & ND & $0.02^{\mathrm{a}} \pm 0.015$ & $0.07^{\mathrm{a}} \pm 0.072$ & ND & ND & ND \\
\hline
\end{tabular}


Table 6. Cont

\begin{tabular}{|c|c|c|c|c|c|c|}
\hline \multirow{4}{*}{$\begin{array}{c}\text { VOCs } \\
\text { Ketones }\end{array}$} & \multicolumn{6}{|c|}{ Cheese Samples } \\
\hline & \multicolumn{3}{|c|}{ ECh } & \multicolumn{3}{|c|}{$\mathrm{CCh}$} \\
\hline & 0 & 30 & 60 & 0 & 30 & 60 \\
\hline & & & & & & \\
\hline 2-Butanone & ND & $0.10^{b} \pm 0.016$ & $0.30^{\mathrm{a}} \pm 0.059$ & ND & $0.21^{c} \pm 0.039$ & ND \\
\hline Diacetyl & ND & $0.59^{b} \pm 0.03$ & $1.42^{\mathrm{a}} \pm 0.280$ & ND & $0.16^{c} \pm 0.160$ & ND \\
\hline Acetoin & $0.10^{c} \pm 0.018$ & $0.24^{b} \pm 0.048$ & $0.59^{a} \pm 0.064$ & $0.04^{c} \pm 0.008$ & $0.48^{\mathrm{a}} \pm 0.073$ & ND \\
\hline 2-Nonanone & $0.04^{b} \pm 0.002$ & $0.07^{b} \pm 0.018$ & $0.41^{\mathrm{a}} \pm 0.291$ & $0.11^{\mathrm{ab}} \pm 0.028$ & $0.41^{\mathrm{a}} \pm 0.001$ & $0.03^{b} \pm 0.030$ \\
\hline 2-Heptanone & $0.04^{b} \pm 0.009$ & $0.04^{b} \pm 0.002$ & $0.39^{\mathrm{a}} \pm 0.194$ & ND & ND & ND \\
\hline 2-Undecanone & ND & $0.01^{\mathrm{c}} \pm 0.009$ & $0.04^{\mathrm{a}} \pm 0.003$ & $0.01^{\mathrm{c}} \pm 0.005$ & $0.03^{b} \pm 0.002$ & ND \\
\hline \multicolumn{7}{|l|}{ Aldehydes } \\
\hline Hexanal & $0.05^{\mathrm{a}} \pm 0.012$ & ND & ND & $0.03^{b} \pm 0.001$ & ND & ND \\
\hline Benzaldehyde & ND & $0.03^{b} \pm 0.014$ & $0.07^{\mathrm{a}} \pm 0.001$ & ND & ND & ND \\
\hline \multicolumn{7}{|l|}{ Terpenes } \\
\hline beta-Pinene & ND & ND & ND & $0.11^{\mathrm{a}} \pm 0.008$ & $0.05^{b} \pm 0.004$ & ND \\
\hline d-Limonene & $0.23^{\mathrm{cd}} \pm 0.092$ & $0.27^{c} \pm 0.109$ & $0.16^{\mathrm{cd}} \pm 0.005$ & $1.53^{\mathrm{a}} \pm 0.034$ & $1.15^{b} \pm 0.128$ & $0.04^{d} \pm 0.039$ \\
\hline \multicolumn{7}{|l|}{ Others } \\
\hline $\begin{array}{l}\text { 6-Pentyl-2H- } \\
\text { pyran-2-one }\end{array}$ & $0.03^{\mathrm{cd}} \pm 0.003$ & $0.05^{c} \pm 0.012$ & $0.15^{\mathrm{a}} \pm 0.02$ & $0.04^{\mathrm{d}} \pm 0.001$ & $0.05^{c} \pm 0.007$ & $0.10^{b} \pm 0.001$ \\
\hline
\end{tabular}

a-e: values in the same line with different superscript letters differ significantly $(p<0.05)$ based on one-way ANOVA followed by Tukey's post-hoc tests. ND not detected.

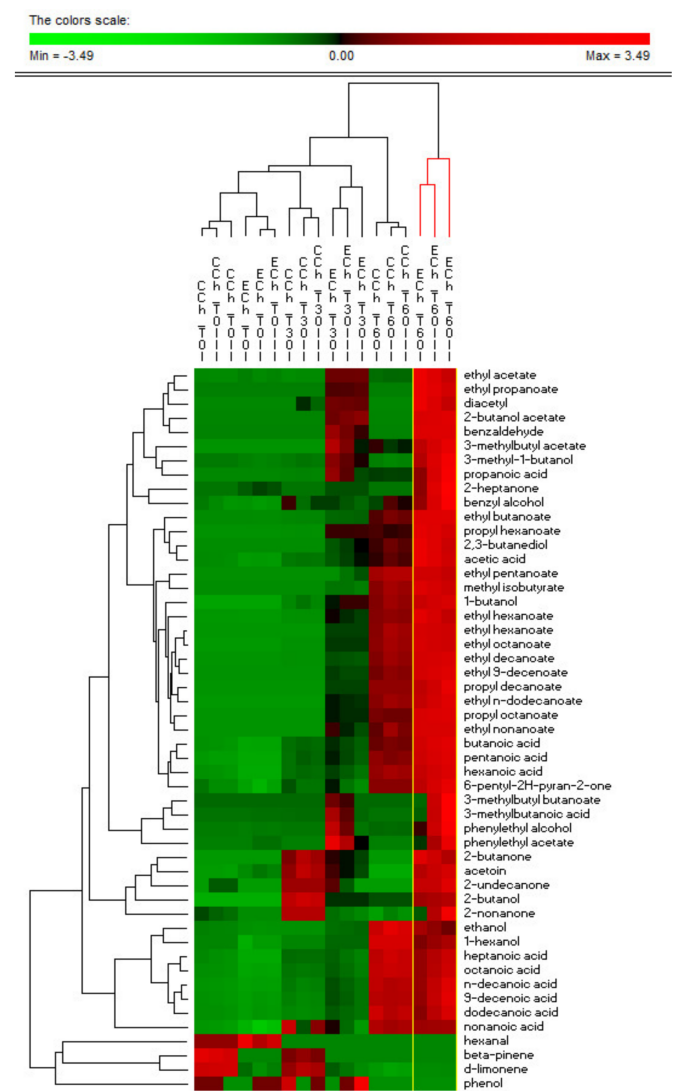

Figure 3. Grouping of samples based on the volatile organic compounds (VOCs) identified in experimental (ECh) and control (CCh) cheeses at 0,30 and 60 days of ripening. The different batch of cheeses are indicated as I, II and III. 


\section{Discussion}

It is already well established that selected NSLAB are mainly used as adjunct culture in cheese production for their ability to contribute to flavour development, affecting the sensorial characteristics of the final product [8,28-30]. The main metabolic activities, which contribute to cheese flavour development, are glycolysis, lipolysis, and proteolysis. In particular, catabolic products of proteolytic reactions represent the major metabolic pathway, which contribute to flavour development [29-31]. According to that, peptidase activity of lactobacilli has been widely investigated [29,30,32].

In the present study, 121 strains were considered LAB and only those with safety properties (86) were tested for technological features, showing a strain-dependent profile in accordance to previously reported data [33-36]. In addition, 27 selected strains were subjected to aminopeptidase tests such as the Pro-p-NA, which is related to the ability to release high quantities of proline from caseins during cheese ripening [37,38]; Pep L, Pep $\mathrm{N}$, and Pep M, which, thanks to the release of amino acids in the cheese environment, serve as precursors of several flavour compounds [38,39]. The screening of the isolates allowed us to select the Lacticaseibacillus paracasei PN 76 and the Limosilactobacillus fermentum PN 101 strains as promising adjunct cultures in a pilot-scale cheese manufacture. In fact, as well as satisfying the safety requirements, both strains showed interesting technological properties (proteolytic activity, abilities to produce both exopolysaccharides and diacetyl). In addition, based on the peptidase activity, the L. fermentum PN 101 exhibited the highest aminopeptidase activity towards both Lys-pNA and Ala-pNA substrates, whereas the $L$. paracasei PN 76 strain showed the highest aminopeptidase activity toward both Leu-pNA and Pro-pNA substrates. As expected, physico-chemical compositions of both experimental and control cheeses were quite similar through ripening, while significant differences were revealed comparing the GC-MS profile. In fact, the experimental cheeses at 30 and 60 days of ripening revealed key flavour compounds which were not detected in the controls. Lipolysis of the triglycerides by indigenous milk lipase, microbial esterase, and enzymes from rennet mainly resulted in the production of medium-chain (hexanoic and octanoic acid) and long-chain free fatty acids (FFAs) [40]. In particular, the experimental cheeses exhibited high concentrations of hexanoic, butanoic, and acetic acids. Although lipoprotein lipase activity is of the utmost importance in cheese varieties made from raw milk, the presence of NSLAB enzymes over an extended period can lead to the liberation of significant FFA levels in cheese [40-42]. According to Stefanovic et al. [43], L. paracasei strains could contribute to the development and diversification of metabolites of lipid origin, such as long chain aldehydes, acids, ketones, and lactones. Among the aforementioned compounds, hexanoic acid, which generates popcorn, sharp, goaty, burnt, and waxy aromas [44,45], has previously been revealed in Pecorino Siciliano PDO cheese, Pecorino Crotonese, Grana Padano, Roncal, Caciocavallo Palermitano and Gouda-type cheeses $[11,33,34,46-50]$ older than 60 ripening days. Similarly to other cheese types, such as Cheddar, Gruyère, Roncal, and Emmental [6,11,46-50], organic acids, important aromatic compounds, as well as precursors of methyl ketones, alcohols, lactones and esters, were the main detected VOCs. In addition, propanoic acid, with a typical vinegary odour, and pentanoic acid, responsible for rain, wood, vegetable, spicy, nutty, and grain aromas, were mainly identified in 60-day ripened experimental cheeses. Some differentiation in volatile profiles occurred based on differences in VOCs arising from FAA metabolism. It is interesting to note that the 3-methylbutanoic acid, a carboxylic acid characteristic of goat and sheep cheeses, appeared only in experimental cheeses. Notably, this organic acid, related to an extensive breakdown of proteins and probably derived from leucine catabolism, confers cheesy, sweaty, and very-ripened cheese aromas [6,11]. Similarly to other cheese-types, such as Parmigiano [50], Canestrato Pugliese cheese [51,52], Grana-type cheeses [50], Gouda-type cheese varieties [48], and other cheese varieties [53], esters were the second major class of detected VOCs. Esters confer sweet, fruity, and floral notes, and contribute to the aroma of cheese by reducing the sharpness and the bitterness perceptions provided by fatty acids and amines, respectively $[11,54]$. Regarding to the alcohol profile 
of experimental cheeses, both primary and secondary alcohols were detected similarly to other cheese types, such as Canestrato Pugliese [51,52], Cheddar [45], Manchego [55] and Roncal [56]. Particularly high level of 3-methyl 1-butanol, phenylethyl alcohol, and benzyl alcohol were detected in experimental cheese at 60 days of ripening. The 3-methyl 1-butanol, which confers an appreciated aroma of fresh cheese, often associated to a fruity perception $[33,34]$, is considered an important contributor to overall flavour. This secondary alcohol is related to the degradation of branched-chain amino acids during cheese ripening, and its presence indicates the reduction of the aldehyde produced from leucine [11]. Regarding the ketones, it is interesting to note that this class of VOCs was revealed only in experimental cheeses. The FFAs' contribution to cheese flavour is not only direct but also indirect, because they are precursors of methyl ketones and secondary alcohols [57]. Ketones derive from the $\beta$-oxidation of fatty acids and are normally present in dairy products. Among these, 2-butanone, responsible for butterscotch aromas and diacetyl were detected in experimental cheeses at high levels.

\section{Conclusions}

In conclusion, the screening of the autochthonous NSLABs, isolated from the Provola dei Nebrodi PDO cheese, based on technological and aminopeptidase properties, allowed the selection of the Lacticaseibacillus paracasei PN 76 and the Limosilactobacillus fermentum PN 101 strains as promising adjunct cultures. Their use in pilot-scale cheese-making trials highlighted a consistent influence on flavour development, starting from 30 days of ripening, contributing to the formation of key flavour compounds.

Author Contributions: Conceptualization, C.L.R., C.C. and A.P.; methodology, C.L.R., M.D.A., G.C., L.L. and K.V.H.; formal analysis, G.C., N.R., A.P., L.L. and K.V.H.; data curation, C.L.R., M.D.A., A.P. and L.L.; writing - original draft preparation, A.P., K.V.H. and L.L.; writing-review and editing, C.L.R., C.C., M.D.A. and V.C. All authors have read and agreed to the published version of the manuscript.

Funding: This work was partially supported by funding from the Ministero dell'Istruzione, dell'Università e della Ricerca, University of Catania (Italy), under the Piano della Ricerca PIA.CE.RI. 20202022 Linea 2-Progetto intradipartimentale RiDARE-Riduzione dell'Antibiotico-Resistenza e della Contaminazione Chimica degli Alimenti (RiDARE). Grant number: UPB 5A722192158.

Institutional Review Board Statement: Not applicable.

Informed Consent Statement: Not applicable.

Data Availability Statement: Not applicable.

Acknowledgments: The authors thank the Marlat s.r.l. dairy company (Messina, Italy) for guesting the pilot-scale cheese-making trials.

Conflicts of Interest: The authors declare no conflict of interest. The funders had no role in the design of the study; in the collection, analyses, or interpretation of data; in the writing of the manuscript, or in the decision to publish the results.

$\begin{array}{ll}\text { Abbreviations } & \\ \text { CCh } & \text { control cheese } \\ \text { CFE } & \text { cell free extract } \\ \text { ECh } & \text { experimental cheese } \\ \text { EPS } & \text { exopolysaccharides } \\ \text { FFAs } & \text { free fatty acids } \\ \text { LAB } & \text { lactic acid bacteria } \\ \text { MALDI-TOF MS } & \text { matrix-assisted laser desorption/ionisation time-of-flight mass spectrometry } \\ \text { MIC } & \text { minimum inhibitory concentration }\end{array}$




$\begin{array}{ll}\text { NSLAB } & \text { non-starter LAB } \\ \text { PDO } & \text { Protected Designation of Origin } \\ \text { PN } & \text { Provola dei Nebrodi } \\ \text { pNA } & \text { p-nitroanilide } \\ \text { QPS } & \text { qualified presumption of safety } \\ \text { SLAB } & \text { starter LAB } \\ \text { VOCs } & \text { volatile organic compounds }\end{array}$

\section{References}

1. Meng, Z.; Zhang, L.; Xin, L.; Lin, K.; Yi, H.; Han, X. Technological characterization of Lactobacillus in semihard artisanal goat cheeses from different Mediterranean areas for potential use as nonstarter lactic acid bacteria. J. Dairy Sci. 2018, 101, $2887-2896$. [CrossRef] [PubMed]

2. Carafa, I.; Nardin, T.; Larcher, R.; Viola, R.; Tuohy, K.; Franciosi, E. Identification and characterization of wild lactobacilli and pediococci from spontaneously fermented mountain cheese. Food Microbiol. 2015, 48, 123-132. [CrossRef] [PubMed]

3. Di Grigoli, A.; Francesca, N.; Gaglio, R.; Guarrasi, V.; Moschetti, M.; Scatassa, M.L.; Settanni, L.; Bonanno, A. The influence of the wooden equipment employed for cheese manufacture on the characteristics of a traditional stretched cheese during ripening. Food Microbiol. 2015, 46, 81-91. [CrossRef] [PubMed]

4. Khattab, A.R.; Guirguis, H.A.; Tawfik, S.M.; Farag, M.A. Cheese ripening: A review on modern technologies towards flavor enhancement, process acceleration and improved quality assessment. Trends Food Sci. Technol. 2019, 88, 343-360. [CrossRef]

5. Beresford, T.P.; Fitzsimons, N.A.; Brennan, N.L.; Cogan, T.M. Recent advances in cheese microbiology. Int. Dairy J. 2001, 11, 259-274. [CrossRef]

6. Yvon, M.; Rejien, L. Cheese flavour formation by amino acid catabolism. Int. Dairy J. 2001, 11, 185-201. [CrossRef]

7. McSweeney, P.L.H.; Sousa, M.J. Biochemical pathways for the production of flavour compounds in cheeses during ripening. A review. Le Lait 2000, 80, 293-324. [CrossRef]

8. Settanni, L.; Moschetti, G. Non-starter lactic acid bacteria used to improve cheese quality and provide health benefits. Food Microbiol. 2010, 27, 691-697. [CrossRef]

9. Savijoki, K.; Ingmer, H.; Varmanen, P. Proteolytic systems of lactic acid bacteria. Appl. Microbiol. Biotechnol. 2006, 71, 394-406. [CrossRef]

10. Čaplová, Z.; Pangallo, D.; Kraková, L.; Puškárová, A.; Drahovská, H.; Bučková, M.; Koreňová, J.; Kuchta, T. Detection of genes prtP, pepN, pepX and bcaT involved in formation of aroma-active compounds in lactic acid bacteria from ewes' cheese. J. Food Nutr. Res. 2018, 57, 195-200.

11. Curioni, P.M.G.; Bosset, J.O. Key odorants in various cheese types as determined by gas chromatography-olfactometry. Int. Dairy J. 2002, 12, 959-984. [CrossRef]

12. Gobbetti, M.; De Angelis, M.; Di Cagno, R.; Mancini, L.; Fox, P.F. Pros and cons for using non-starter lactic acid bacteria (NSLAB) as secondary/adjunct starters for cheese ripening. Trends Food. Sci. Technol. 2015, 45, 167-178. [CrossRef]

13. Pino, A.; Van Hoorde, K.; Pitino, I.; Russo, N.; Carpino, S.; Caggia, C.; Randazzo, C.L. Survival of potential probiotic lactobacilli used as adjunct cultures on Pecorino Siciliano cheese ripening and passage through the gastrointestinal tract of healthy volunteers. Int. J. Food Microbiol. 2017, 252, 42-52. [CrossRef] [PubMed]

14. Pino, A.; Liotta, L.; Randazzo, C.L.; Todaro, A.; Mazzaglia, A.; De Nardo, F.; Chiofalo, V.; Caggia, C. Polyphasic approach to study physico-chemical, microbiological and sensorial characteristics of artisanal Nicastrese goat's cheese. Food Microbiol. 2018, 70, 143-154. [CrossRef]

15. Nguyen, T.L.D.; Van Hoorde, K.; Cnockaert, M.; De Brandt, E.; Aerts, M.; Le, B.T.; Vandamme, P. A description of the lactic acid bacteria microbiota associated with the production of traditional fermented vegetables in Vietnam. Int. J. Food Microbiol. 2013, 163, 19-27. [CrossRef] [PubMed]

16. Pino, A.; Russo, N.; Van Hoorde, K.; De Angelis, M.; Sferrazzo, G.; Randazzo, C.L.; Caggia, C. Piacentinu Ennese PDO Cheese as Reservoir of Promising Probiotic Bacteria. Microorganisms 2019, 7, 254. [CrossRef]

17. Muñoz-Atienza, E.; Gómez-Sala, B.; Araújo, C.; Campanero, C.; del Campo, R.; Hernández, P.E. Antimicrobial activity, antibiotic susceptibility and virulence factors of lactic acid bacteria of aquatic origin intended for use as probiotics in aquaculture. $B M C$ Microbiol. 2013, 13, 15. [CrossRef]

18. Pino, A.; Bartolo, E.; Caggia, C.; Cianci, A.; Randazzo, C.L. Detection of vaginal lactobacilli as probiotic candidates. Sci. Rep. 2019, 9, 3355. [CrossRef]

19. Bover-Cid, S.; Holzapfel, W.H. Improved screening procedure for biogenic amine production by lactic acid bacteria. Int. J. Food Microbiol. 1999, 53, 33-41. [CrossRef]

20. EFSA Panel on Additives and Products or Substances used in Animal Feed (FEEDAP). Guidance on the assessment of bacterial susceptibility to antimicrobials of human and veterinary importance. EFSA J. 2012, 10, 2740.

21. Russo, N.; Caggia, C.; Pino, A.; Coque, T.M.; Arioli, S.; Randazzo, C.L. Enterococcus spp. in Ragusano PDO and Pecorino Siciliano cheese types: A snapshot of their antibiotic resistance distribution. Food Chem. Toxicol. 2018, 120, 277-286. [CrossRef] [PubMed] 
22. Ferrari, I.S.; de Souza, J.V.; Ramos, C.L.; da Costa, M.M.; Schwan, R.F.; Dias, F.S. Selection of autochthonous lactic acid bacteria from goat dairies and their addition to evaluate the inhibition of Salmonella typhi in artisanal cheese. Food Microbiol. 2016, 60, 29-38. [CrossRef] [PubMed]

23. Ribeiro, S.C.; Coelho, M.C.; Todorov, S.D.; Franco, B.D.; Dapkevicius, M.L.; Silva, C.C. Technological properties of bacteriocinproducing lactic acid bacteria isolated from Pico cheese an artisanal cow's milk cheese. J. Appl. Microbiol. 2014, 116, 573-585. [CrossRef] [PubMed]

24. González, L.; Sacristán, N.; Arenas, R.; Fresno, J.M.; Tornadijo, E.M. Enzymatic activity of lactic acid bacteria (with antimicrobial properties) isolated from a traditional Spanish cheese. Food Microbiol. 2010, 27, 592-597. [CrossRef]

25. Association of Official Analytical Chemists (AOAC). Official Methods of Analysis, 21st ed.; AOAC International: Gaithersburg, MD, USA, 2019.

26. Delgado, F.J.; González-Crespo, J.; Cava, R.; Ramírez, R. Formation of the aroma of a raw goat milk cheese during maturation analysed by SPME-GC-MS. Food Chem. 2011, 129, 1156-1163. [CrossRef]

27. Montemurro, M.; Celano, G.; De Angelis, M.; Gobbetti, M.; Rizzello, C.G.; Pontonio, E. Selection of non-Lactobacillus strains to be used as starters for sourdough fermentation. Food Microbiol. 2020, 90, 103491. [CrossRef]

28. Sgarbi, E.; Lazzi, C.; Tabanelli, G.; Gatti, M.; Neviani, E.; Gardini, F. Nonstarter lactic acid bacteria volatilomes produced using cheese components. J. Dairy Sci. 2013, 96, 4223-4234. [CrossRef]

29. Peralta, G.H.; Bergamini, C.V.; Wolf, I.V.; Perotti, M.C.; Hynes, E.R. Adjunct cultures from non-starter lactic acid bacteria. In Cheese Production, Consumption and Health Benefits; Henriques, M.H.F., Pereira, C.J.D., Eds.; Nova Science Publishers, Inc.: Hauppauge, NY, USA, 2017; Volume 1, pp. 39-96.

30. Pintado, M.; Da Cruz, A.G.; De Sá, P.B.Z.R. Cheese microbiology. In Dairy Microbiology and Biochemistry: Recent Developments; Özer, B.H., Akdemir-Evrendilek, G., Eds.; CRC Press/Taylor \& Francis: Boca Raton, FL, USA, 2014; Volume 1, pp. 113-133.

31. Smit, G.; Smit, B.A.; Engels, W.J.M. Flavour formation by lactic acid bacteria and biochemical flavour profiling of cheese products. FEMS Microbiol. Rev. 2005, 29, 591-610. [CrossRef]

32. Van Hoorde, K.; Van Landschoot, A. Application of adjunct-cultures and their influence on the sensory properties of hard and semi-hard cheese varieties. In Book on Beneficial Microbes in Fermented and Functional Foods; Rai, V.R., Bai, J.A., Eds.; CRC Press/Taylor \& Francis Group: Boca Raton, FL, USA, 2014; pp. 531-550.

33. Randazzo, C.L.; De Luca, S.; Todaro, A.; Restuccia, C.; Lanza, C.M.; Spagna, G.; Caggia, C. Preliminary characterization of wild lactic acid bacteria and their abilities to produce flflflavour compounds in ripened model cheese system. J. Appl. Microbiol. 2007, 103, 427-443. [CrossRef]

34. Randazzo, C.L.; Pitino, I.; Ribbera, A.; Caggia, C. Pecorino Crotonese cheese: Study of bacterial population and flavour compounds. Food Microbiol. 2010, 27, 363-374. [CrossRef]

35. Guarcello, R.; Carpino, S.; Gaglio, R.; Pino, A.; Rapisarda, T.; Caggia, C.; Marino, G.; Randazzo, C.L.; Settanni, L.; Todaro, M. A large factory-scale application of selected autochthonous lactic acid bacteria for PDO Pecorino Siciliano cheese production. Food Microbiol. 2016, 59, 66-75. [CrossRef] [PubMed]

36. Carpino, S.; Randazzo, C.L.; Pino, A.; Russo, N.; Rapisarda, T.; Belvedere, G.; Caggia, C. Influence of PDO Ragusano cheese biofilm microbiota on flavour compounds formation. Food Microbiol. 2017, 61, 126-135. [CrossRef] [PubMed]

37. Aquilanti, L.; Silvestri, G.; Zannini, E.; Osimani, A.; Santarelli, S.; Clementi, F. Phenotypic, genotypic and technological characterization of predominant lactic acid bacteria in Pecorino cheese from central Italy. J. Appl. Microbiol. 2007, 103, 948-960. [CrossRef] [PubMed]

38. Nandan, A.; Nampoothiri, K.M. Therapeutic and biotechnological applications of substrate specific microbial aminopeptidases. Appl. Microbiol. Biotechnol. 2020, 28, 1-15. [CrossRef]

39. Piraino, P.; Zotta, T.; Ricciardi, A.; McSweeney, P.L.H.; Parente, E. Acid production, proteolysis, autolytic and inhibitory properties of lactic acid bacteria isolated from pasta filata cheeses: A multivariate screening study. Int. Dairy J. 2008, 18, 81-92. [CrossRef]

40. Collins, Y.F.; McSweeney, P.L.H.; Wilkinson, M.G. Lipolysis and free fatty acid catabolism in cheese: A review of current knowledge. Int. Dairy J. 2003, 13, 841-866. [CrossRef]

41. Deeth, H.C. Lipoprotein lipase and lipolysis in milk. Int. Dairy J. 2006, 16, 555-562. [CrossRef]

42. Thierry, A.; Collins, Y.F.; Abeijón Mukdsi, M.C.; McSweeney, P.L.H.; Wilkinson, M.G.; Spinnler, H.E. Lipolysis and Metabolism of Fatty Acids in Cheese. Cheese 2017, 423-444.

43. Stefanovic, E.; Kilcawley, K.N.; Roces, C.; Rea, M.C.; O'sullivan, M.; Sheehan, J.J.; McAuliffe, O. Evaluation of the potential of Lactobacillus paracasei adjuncts for flavor compounds development and diversification in short-aged cheddar cheese. Front. Microbiol. 2018, 9, 1506. [CrossRef]

44. Frank, D.C.; Owen, C.M.; Patterson, J. Solid phase microextraction (SPME) combined with gas chromatography and olfactometryMass spectrometry for characterization of cheese aroma compounds. LWT-Food Sci. Technol. 2004, 37, 139-154. [CrossRef]

45. Drake, M.A.; Miracle, R.E.; McMahon, D.J. Impact of fat reduction on flavour and flavour chemistry of Cheddar cheeses. J. Dairy Sci. 2010, 93, 81. [CrossRef] [PubMed]

46. Gaglio, R.; Franciosi, E.; Todaro, A.; Guarcello, R.; Alfeo, V.; Randazzo, C.L.; Settanni, L.; Todaro, M. Addition of selected starter/non-starter lactic acid bacterial inoculums to stabilise PDO Pecorino Siciliano cheese production. Food Res. Int. 2020, 136, 109335. [CrossRef] [PubMed] 
47. Guarrasi, V.; Sannino, C.; Moschetti, M.; Bonanno, A.; Di Grigoli, A.; Settanni, L. The individual contribution of starter and non-starter lactic acid bacteria to the volatile organic compound composition of Caciocavallo Palermitano cheese. Int. J. Food Microbiol. 2017, 259, 35-42. [CrossRef] [PubMed]

48. Shiota, M.; Iwasawa, A.; Suzuki-Iwashima, A.; Iida, F. Effects of Flavor and Texture on the Sensory Perception of Gouda-Type Cheese Varieties during Ripening Using Multivariate Analysis. J. Food Sci. 2015, 80, 2740-2750. [CrossRef] [PubMed]

49. Ercolini, D.; Frisso, G.; Mauriello, G.; Salvatore, F.; Coppola, S. Microbial diversity in natural whey cultures used for the production of Caciocavallo Silano PDO cheese. Int. J. Food Microbiol. 2008, 124, 164-170. [CrossRef]

50. Bellesia, F.; Pinetti, A.; Pagnoni, U.G.; Rinaldi, R.; Zucchi, C.; Caglioti, L.; Palyi, G. Volatile components of Grana ParmigianoReggiano type hard cheese. Food Chem. 2003, 83, 55-61. [CrossRef]

51. Di Cagno, R.; Banks, J.; Sheehan, L.; Fox, P.F.; Brechany, E.Y.; Corsetti, A.; Gobbetti, M. Comparison of the microbiological, compositional, biochemical, volatile profile and sensory characteristics of three Italian PDO ewes' milk cheeses. Int. Dairy J. 2003, 13, 961-972. [CrossRef]

52. Di Cagno, R.; Upadhyay, V.K.; McSweeney, P.L.H.; Corbo, M.R.; Faccia, M.; Gobbetti, M. Microbiological, compositional and biochemical characterisation of PDO Canestrato Pugliese cheese. Ital. J. Food Sci. 2004, 16, 45-58.

53. Liu, S.Q.; Holland, R.; Crow, V.L. Esters and their biosynthesis in fermented dairy products: A review. Int. Dairy J. 2004, 14, 923-945. [CrossRef]

54. Pinho, O.; Mendes, E.; Alves, M.M.; Ferreira, I.M.P.L.V.O. Chemical, Physical, and Sensorial Characteristics of "Terrincho" Ewe Cheese: Changes During Ripening and Intravarietal Comparison. J. Dairy Sci. 2004, 87, 249-257. [CrossRef]

55. Fernández-García, E.; Serrano, C.; Nuñez, M. Volatile fraction and sensory characteristics of Manchego cheese. 2. Seasonal variation. J. Dairy Res. 2002, 69, 595-604. [CrossRef] [PubMed]

56. Izco, J.M.; Torre, P. Characterisation of volatile flavour compounds in Roncal cheese extracted by the 'purge and trap' method and analysed by GC-MS. Food Chem. 2000, 70, 409-417. [CrossRef]

57. Bertuzzi, A.S.; McSweeney, P.L.H.; Rea, M.C.; Kilcawley, K.N. Detection of Volatile Compounds of Cheese and Their Contribution to the Flavor Profile of Surface-Ripened Cheese. Compr. Rev. Food Sci. Food 2018, 17, 371-390. [CrossRef] [PubMed] 